\section{Check for updates}

Cite this: Phys. Chem. Chem. Phys., 2021, 23, 21419

Received 29th June 2021 . Accepted 15th September 2021 DOI: $10.1039 / d 1 c p 02946 k$

rsc.li/pccp

\title{
Solvate electrolytes for $\mathrm{Li}$ and $\mathrm{Na}$ batteries: structures, transport properties, and electrochemistry
}

\author{
Yosuke Ugata, $\dagger^{\mathrm{a}}$ Keisuke Shigenobu, $\dagger^{\mathrm{a}}$ Ryoichi Tatara, (D) ${ }^{\mathrm{bc}}$ Kazuhide Ueno, (D) ad \\ Masayoshi Watanabe (D) ${ }^{d}$ and Kaoru Dokko (D) *acd
}

\begin{abstract}
Polar solvents dissolve $\mathrm{Li}$ and $\mathrm{Na}$ salts at high concentrations and are used as electrolyte solutions for batteries. The solvents interact strongly with the alkali metal cations to form complexes in the solution. The activity (concentration) of the uncoordinated solvent decreases as the salt concentration is increased. At extremely high salt concentrations, all the solvent molecules are involved in the coordination of the ions and form the solvates of the salts. In this article, we review the structures, transport properties, and electrochemistry of Li/Na salt solvates. In molten solvates, the activity of the uncoordinated solvent is negligible; this is the main origin of their peculiar characteristics, such as high thermal stability, wide electrochemical window, and unique ion transport. In addition, the solvent activity greatly influences the electrochemical reactions in Li/Na batteries. We highlight the attractive features of molten solvates as promising electrolytes for next-generation batteries.
\end{abstract} (20.

\section{Introduction}

${ }^{a}$ Department of Chemistry and Life Science, Yokohama National University, 79-5 Tokiwadai, Hodogaya-ku, Yokohama 240-8501, Japan E-mail:dokko-kaoru-js@ynu.ac.jp

${ }^{b}$ Department of Applied Chemistry, Tokyo University of Science, 1-3 Kagurazaka, Shinjuku, Tokyo 162-8601, Japan

${ }^{c}$ Unit of Elements Strategy Initiative for Catalysts \& Batteries (ESICB), Kyoto University, Kyoto 615-8510, Japan

${ }^{d}$ Advanced Chemical Energy Research Center, Institute of Advanced Sciences, Yokohama National University, 79-5 Tokiwadai, Hodogaya-ku, Yokohama 240-8501, Japan

$\dagger$ These authors contributed equally to this work.

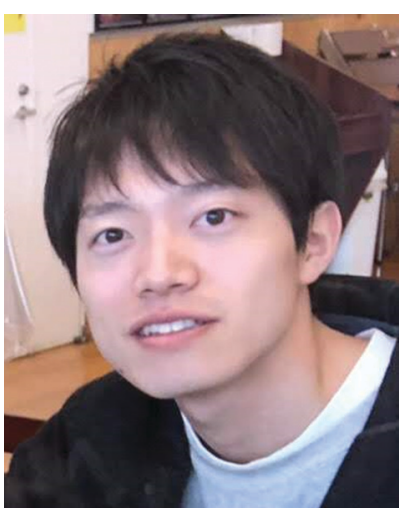

Yosuke Ugata
Yosuke Ugata was born in Kanagawa, Japan in 1995. He received his Bachelor's (2018) and Master's (2020) degrees from Yokohama National University (YNU) under the supervision of Prof. Kaoru Dokko, Prof. Kazuhide Ueno, and Prof. Masayoshi Watanabe. He is a $P h D$ candidate and studying the ion transport and electrochemical properties of liquid electrolytes for Li-based secondary batteries.

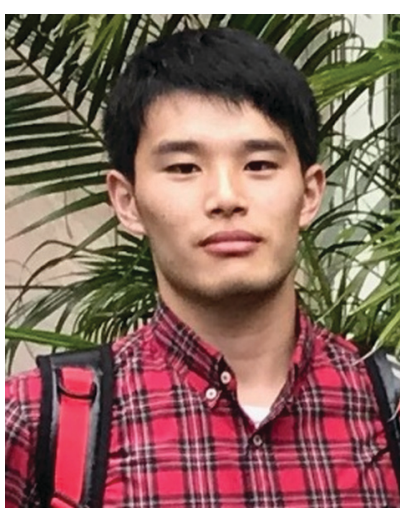

Keisuke Shigenobu recieved BS (2018) and MS (2020) degrees from Yokohama National University, where he is currently pursuing his PhD in the group of Prof. Kaoru Dokko and Prof. Kazuhide Ueno. His current research interests include studies of ion dynamics in the electrolyte solutions and the electrolyte design for the next generation batteries.
Keisuke Shigenobu 
Currently, the electrolytes used in lithium-ion batteries (LIBs) are Li salts dissolved in an aprotic solvent at a concentration of approximately $1 \mathrm{~mol} \mathrm{dm}^{-3,}$, and the electrolyte shows the maximum ionic conductivity at this concentration. ${ }^{2}$ The ionic conductivity $(\sigma)$ can be written as ${ }^{3}$

$$
\sigma=\sum_{i} N_{i}\left|q_{i}\right| \mu_{i}
$$

where $N$ is the number of carriers per unit volume, $q$ is the electric charge per carrier, and $\mu$ is the carrier mobility. The number of carriers increases with the increase in the concentration of the salt, whereas the mobility decreases as the viscosity of the solution increases with increasing salt concentration, i.e. there is a trade-off relationship between the number of carriers and carrier mobility. This trade-off relationship results in maximum ionic conductivity at a salt concentration of approximately $1 \mathrm{~mol} \mathrm{dm}^{-3}$. Because electrolyte solutions with salt concentrations higher than $1 \mathrm{~mol} \mathrm{dm}^{-3}$ have low ionic conductivities owing to high viscosities, it was believed that there is no advantage in adding large amounts of expensive Li salts to the electrolyte. However, nowadays, researchers are extensively investigating "superconcentrated" or "solvent-in-salt" electrolytes with $\mathrm{Li}$ salt dissolved at a concentration exceeding $\sim 3 \mathrm{~mol} \mathrm{dm}^{-3}$ because certain super-concentrated electrolytes have been reported to improve the performance of lithium batteries. ${ }^{4-9}$ Increasing the salt concentration in a solution decreases its solvent/salt molar ratio. In aprotic electrolyte solutions, the coordination numbers

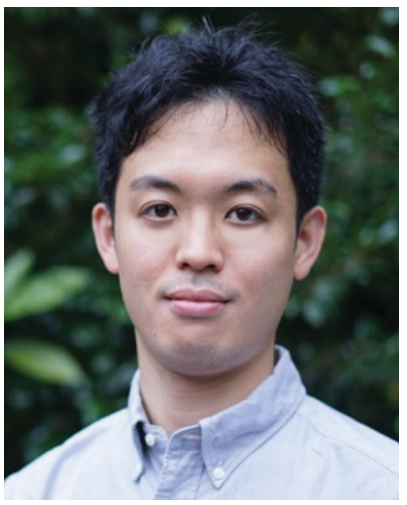

Ryoichi Tatara
Ryoichi Tatara is an Assistant Professor at the Tokyo University of Science. He received his PhD from Yokohama National University in 2017 under the supervision of Prof. Masayoshi Watanabe and Prof. Kaoru Dokko. He subsequently worked at Massachusetts Institute of Technology as a postdoctoral associate with Prof. Yang ShaoHorn. In 2020, he joined the Tokyo University of Science. His current research interests include the physicochemical properties of electrolyte solutions, interfacial chemistry at the electrode/electrolyte interface, and electrochemical reactions in $\mathrm{Li} / \mathrm{Na} / \mathrm{K}$ batteries.

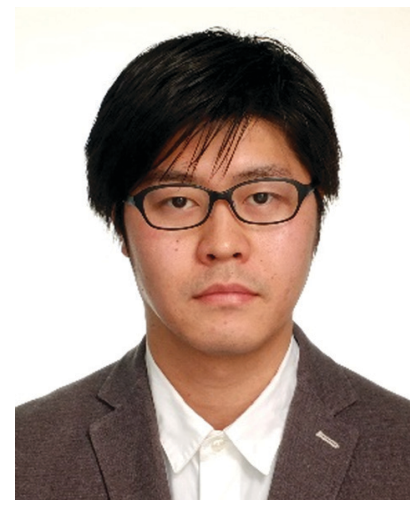

Kazuhide Ueno
Kazuhide Ueno is an Associate Professor at Yokohama National University. He received his $P h D$ degrees in 2009 with Prof. $M$. Watanabe from Yokohama National University. He was a postdoctoral fellow at Tohoku University working with Prof. $K$. Kurihara, at Arizona State University working with Prof. C. Austen Angell, and at Yokohama National University. In 2015, he was appointed as assistant professor at Yamaguchi University. His research interests include ionic liquid-based soft materials and battery electrolytes.

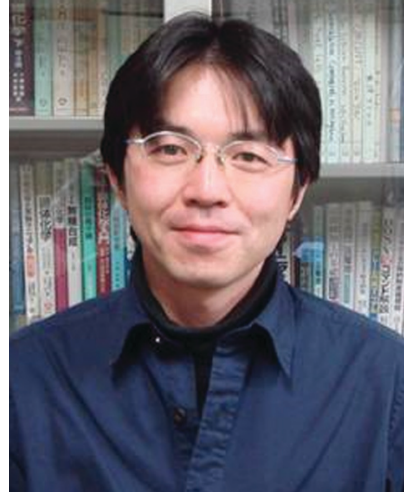

Kaoru Dokko
Kaoru Dokko is a Professor at Yokohama National University. $\mathrm{He}$ received $\mathrm{PhD}$ from Tohoku University in 2001 under the supervision of Prof. Isamu Uchida. He was a postdoctoral researcher at Case Western Reserve University and Tokyo Metropolitan University. $\mathrm{He}$ joined Yokohama National University in 2008. His current research interests are the physicochemical properties of concentrated electrolytes, nanoScience, Japan in 2006, the Award of The Electrochemical Society of Japan (Takei Award) and ECS Max Bredig Award in 2016, and The Chemical Society of Japan Award in 2021. His current research interests are the materials design of ionic liquids and polymers for electrochemical applications and phase-behaviour and self-assembly of polymers and colloids in ionic liquids. 
Typical electrolyte $\left(\sim 1 \mathrm{~mol} \mathrm{dm}^{-3}\right)$

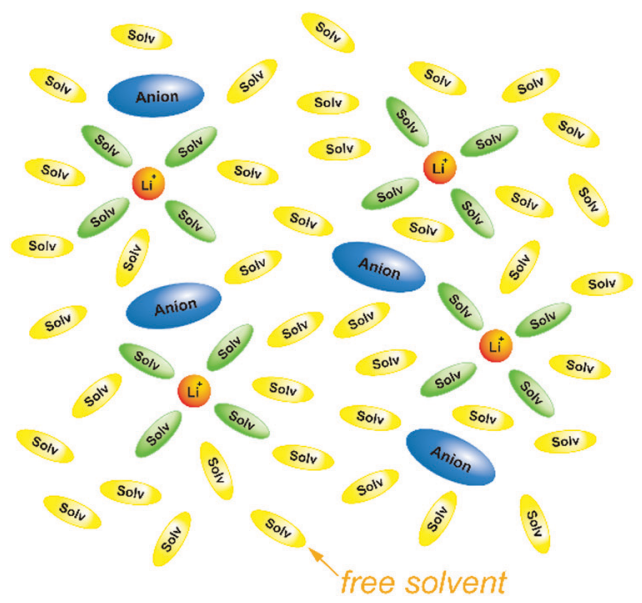

Molten solvate electrolyte $\left(>3 \mathrm{~mol} \mathrm{dm}^{-3}\right)$

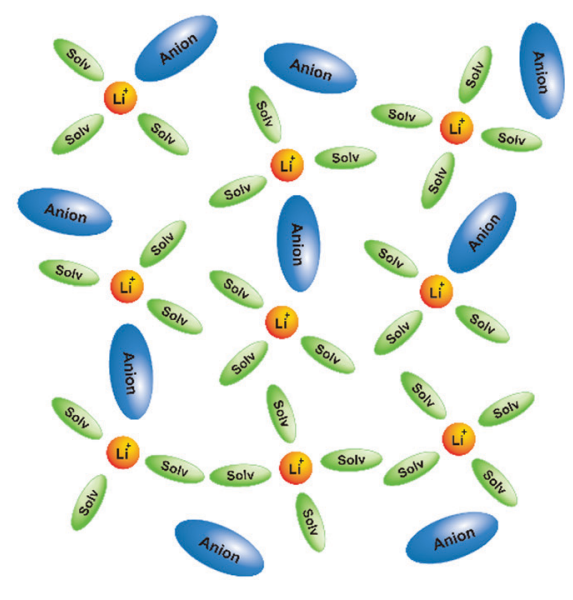

Fig. 1 Schematic illustrations of solvation structures in a typical Li salt electrolyte solution ( $1 \mathrm{~mol} \mathrm{dm}^{-3}$ ) and a molten Li salt solvate electrolyte $\left(>3 \mathrm{~mol} \mathrm{dm}^{-3}\right.$ ). In a typical electrolyte solution containing excess solvent, each $\mathrm{Li}^{+}$ion forms a complex with 4 or 5 solvent molecules, and uncoordinated (free) solvent molecules exist abundantly. In a molten solvate electrolyte, $\mathrm{Li}^{+}$ions form complexes with solvents and anions, and free solvent hardly exists.

of $\mathrm{Li}^{+}$and $\mathrm{Na}^{+}$are typically $4-6$ and $5-7$, respectively. ${ }^{10-14}$ In highly concentrated solutions with molar ratios of solvent/salt lower than the coordination number of the cations, almost all the solvent molecules are coordinated to $\mathbf{M}^{+}$ions, and free (uncoordinated) solvent molecule hardly exists in the solution (Fig. 1). In addition, the anions also participate in the coordination of the $\mathrm{M}^{+}$ions to satisfy the coordination number of $\mathrm{M}^{+}$ion. These highly concentrated solutions without free solvent molecules are regarded as "molten solvates".

Henderson et al. systematically investigated the crystal structures of glyme solvates of Li salts; ${ }^{15-18}$ moreover, we reported the physicochemical properties and battery applications of molten glyme solvates. ${ }^{19-23}$ Glyme molecules $\left(\mathrm{CH}_{3} \mathrm{O}\left(\mathrm{CH}_{2-}\right.\right.$ $\left.\mathrm{CH}_{2} \mathrm{O}\right)_{n} \mathrm{CH}_{3}$ ) serve as multidentate ligands and form long-lived complexes with alkali metal cations in the solution. ${ }^{24}$ The triglyme (G3) and tetraglyme (G4) molecules have 4 and 5 oxygen atoms, respectively, and the number of oxygen atoms matches the coordination number of $\mathrm{Li}^{+}$. The G3 and G4 coordinate to $\mathrm{Li}^{+}$ in a molar ratio of $1: 1$, and form $[\mathrm{Li}(\mathrm{G} 3)]^{+}$and $[\mathrm{Li}(\mathrm{G} 4)]^{+}$ in solutions, respectively. The 1:1 mixtures of G3 (or G4) and certain Li salts, such as LiTFSA and LiBETA (BETA: bis(pentafluoroethanesulfonyl)amide), are regarded as ionic liquids composed of complex cations $[\mathrm{Li}(\mathrm{G} 3 \text { or } \mathrm{G} 4)]^{+}$and the counter anions are regarded as "solvate ionic liquids". Earlier, we have reviewed the physicochemical properties and electrochemistry of glyme-solvate ionic liquids. ${ }^{25-27}$ The present article reviews recent progress in the researches on molten solvates and highly concentrated electrolytes comprising various aprotic solvents and Li/Na salts (Fig. 2). The molten Li salt hydrate electrolytes, so called "water-in-salt" electrolytes, which enable the stable operation of 3 V-class aqueous LIBs have also been extensively studied; ${ }^{28-30}$ however, these aqueous electrolytes do not have sufficient reductive stability against Li metal. The molten solvate electrolytes with aprotic solvents possess high thermal stability and wide electrochemical window and are promising electrolytes for next-generation batteries, such as high voltage $\mathrm{Li} / \mathrm{Na}$ batteries, ${ }^{31-37} \mathrm{Li}-\mathrm{O}_{2}$ batteries, ${ }^{38}$ and $\mathrm{Li}-\mathrm{S}$ batteries. ${ }^{39} \mathrm{Li}$ metal is one of the most attractive anode materials owing to its high theoretical capacity ( $3860 \mathrm{~mA} \mathrm{~h} \mathrm{~g}{ }^{-1}$ ) and low electrode potential $\left(-3.04 \mathrm{~V}\right.$ vs. SHE). ${ }^{40-50}$ Highly concentrated aprotic electrolytes have been reported to be useful in achieving a high Coulombic efficiency of Li metal deposition/stripping and a long charge/ discharge cycle life of $\mathrm{Li}$ metal batteries. ${ }^{33,51-56}$ In addition to these attractive features, we recently found that a unique transport process of $\mathrm{Li} / \mathrm{Na}$ ions emerges in highly concentrated electrolytes. ${ }^{31}$ The Li/Na cations exchange ligands (solvent and anion) rapidly in certain concentrated electrolytes, which enables them to diffuse faster than the solvent molecules and anions in the solutions, resulting in the high transference numbers of $\mathrm{Li} / \mathrm{Na}$ ions. The high transference numbers are effective in suppressing the concentration polarization of $\mathrm{Li} / \mathrm{Na}$ batteries during discharging at high current densities and may be useful in improving the power densities of the batteries.

We highlight the unique features of molten solvates as promising electrolytes for next-generation batteries. With increasing the salt concentration in the electrolytes, the activity (concentration) of solvent decreases. So far, the effects of solvent activity on the physicochemical properties of the electrolytes and the electrochemical reaction processes in the electrolytes have often been overlooked. In molten solvates, the activity of the free solvent is negligible, which is the main origin of their unique physicochemical properties. In the following Section 2, the effects of activity of free solvent in electrolytes on the equilibrium of electrochemical reactions and the thermal stability of the electrolytes are discussed. The activity of free solvent is negligible in the molten solvate electrolytes, and this significantly affects the thermodynamic properties of the electrolytes. In Section 3, the crystal and liquid structures of solvate electrolytes are reviewed, and the correlation between liquid structures and ion transport properties of the molten solvate electrolytes is discussed in Section 4. Finally, the application of solvate electrolytes to next generation batteries is 

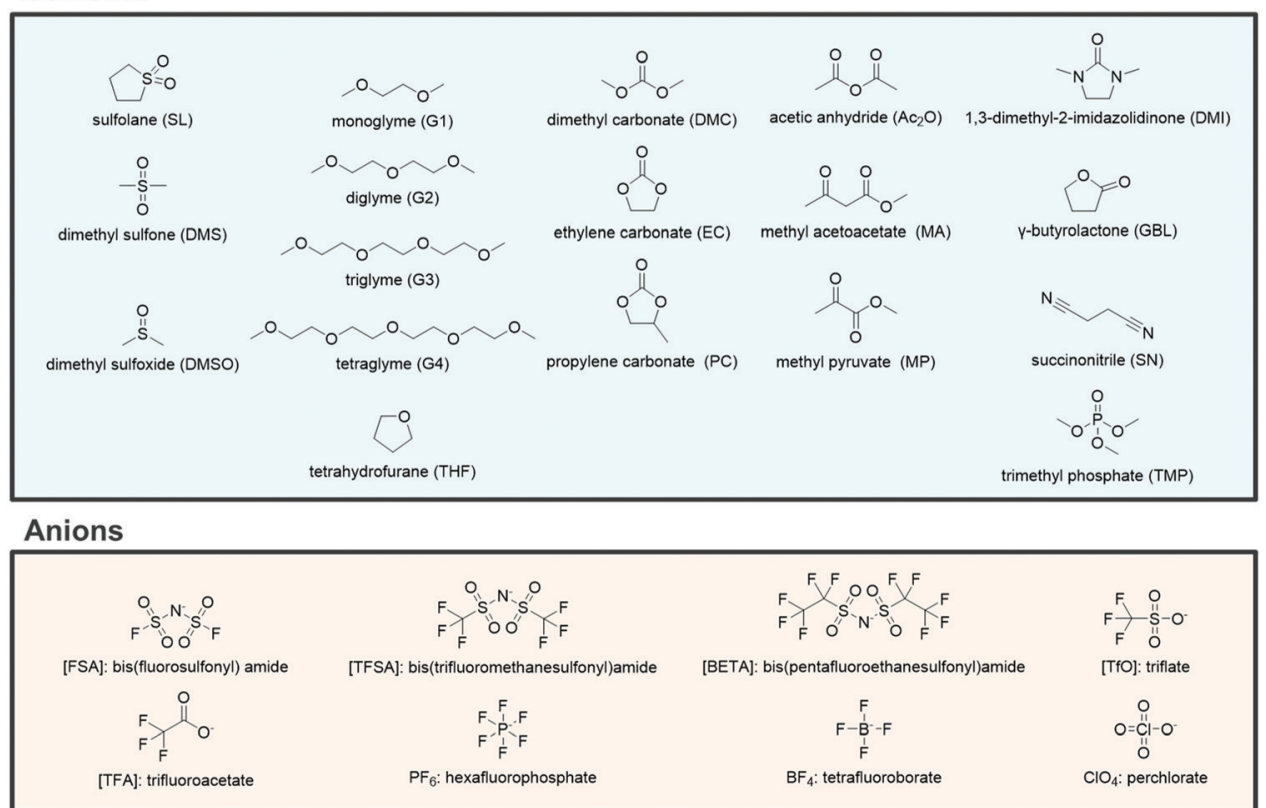

Fig. 2 Chemical structures and abbreviations of the various solvents and anions.

demonstrated in Section 5. The solvent activity and the ion transport properties of the molten solvate electrolytes greatly influence the charge-discharge performance of $\mathrm{Li} / \mathrm{Na}$ batteries.

\section{Effects of solvent activity and solvated ion activity}

\subsection{Electrode potential}

In case of the Li deposition/stripping reactions, the solvated $\mathrm{Li}^{+},\left[\mathrm{Li}(\text { solvent })_{n}\right]^{+}$, reacts at the electrode, and the desolvation/ solvation of $\mathrm{Li}^{+}$occur as shown in eqn (2). The equilibrium electrode potential, $E$, of the electrochemical reaction is described by the Nernst eqn (3) using the activity of the species in the system. ${ }^{57}$

$$
\begin{gathered}
\left.[\text { Li(solvent })_{n}\right]^{+}+\mathrm{e}^{-} \rightleftarrows \mathrm{Li}+n \text { solvent } \\
E=E^{\mathrm{o}}+\frac{R T}{F} \ln \frac{a\left(\left[\operatorname{Li}(\text { solvent })_{n}\right]^{+}\right)}{a_{\text {solvent }}^{n}}
\end{gathered}
$$

where $E^{\circ}$ is the standard electrode potential for eqn (2), $R$ is the gas constant, $T$ is the absolute temperature, $F$ is the Faraday constant, $a\left(\left[\operatorname{Li}(\text { solvent })_{n}\right]^{+}\right)$and $a_{\text {solvent }}$ are the activities of $\left.[\text { Li(solvent })_{n}\right]^{+}$and the uncoordinated (free) solvent, respectively. Activity of an ionic species in an electrolyte solution is a measure of the effective concentration under non-ideal condition, defined as $a=\gamma_{ \pm} c$, where $c$ and $\gamma_{ \pm}$are the concentration and the mean activity coefficient of the electrolyte salt, respectively. Conventionally, the activity of free solvent in an electrolyte solution has been assumed to be constant, i.e., $a_{\text {solvent }}=1$. This assumption is based on that the mole fraction of solvent ( $\left.x_{\text {solvent }}\right)$ is nearly unity in a dilute electrolyte solution (a mixture of a large excess solvent and a small amount of salt), and $a_{\text {solvent }}=f x_{\text {solvent }} \approx 1$ where $f$ is the activity coefficient of solvent. This is definitely valid for a dilute electrolyte containing abundant free solvent, and a linear relation between $E$ and $\log c_{\mathrm{Li}}$ (where $c_{\mathrm{Li}}$ is the concentration of Li salt) can be observed in the low concentration region as shown in Fig. 3. The electrode potential of Li metal is linear to $\log c_{\mathrm{Li}}$ at lower than $1 \mathrm{~mol} \mathrm{dm}^{-3}\left(\log c_{\mathrm{Li}}=0\right)$, however, the potential deviates from linearity and shifts significantly to a positive potential at concentrations above $1 \mathrm{~mol} \mathrm{dm}^{-3} \cdot{ }^{58,59}$ With increasing the Li salt concentration, the mole fraction of solvent $x_{\text {solvent }}$ decreases, and the activity of free solvent is no longer assumed to be 1, i.e., $a_{\text {solvent }}$ becomes lower than 1. Actually, the mole fraction of free solvent in molten glyme solvates of Li salts was very low, which was revealed by Raman spectroscopy. ${ }^{59}$ In addition, Arai et al. measured the vapor-pressure of $\mathrm{Li}$ salt solutions and concluded that the activity coefficients of solvents in highly concentrated solutions were considerably lower than $1 .{ }^{60}$ Therefore, the nonlinear relationship between $E$ and $\log c_{\mathrm{Li}}$ in the high concentration region $>1 \mathrm{~mol} \mathrm{dm}^{-3}$ (Fig. 3) is reasonably attributed to the decrease in free solvent activity. The effects of the considerably low activity of free solvent in the molten solvate electrolytes on the electrochemical reactions in batteries will be discussed later.

\subsection{Effects of solvent species}

The standard electrode potential $E^{\circ}$ of the Li metal electrode (eqn (3)) can be described as follows:

$$
E^{\circ}=\frac{\left.\Delta_{f} G^{\circ}\left(\left[\operatorname{Li}(\text { solvent })_{n}\right]^{+}\right)-n \Delta_{f} G^{\circ} \text { (solvent }\right)}{F}
$$

where $\Delta_{f} G^{\circ}\left(\left[\operatorname{Li}(\text { solvent })_{n}{ }^{+}\right]\right)$and $\Delta_{f} G^{\circ}$ (solvent) are the standard Gibbs energies for the formation of solvated $\mathrm{Li}^{+}$ions $\left.\left([\text { Li(solvent })_{n}\right]^{+}\right)$and free solvent, respectively. Fig. 3a shows the order of the electrode potentials of $\mathrm{Li}$ metal electrode in different ether solvents at salt concentrations less than 
(a)

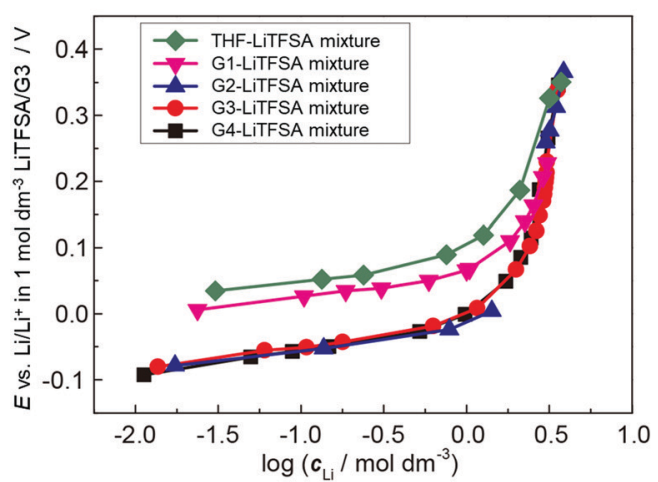

(b)

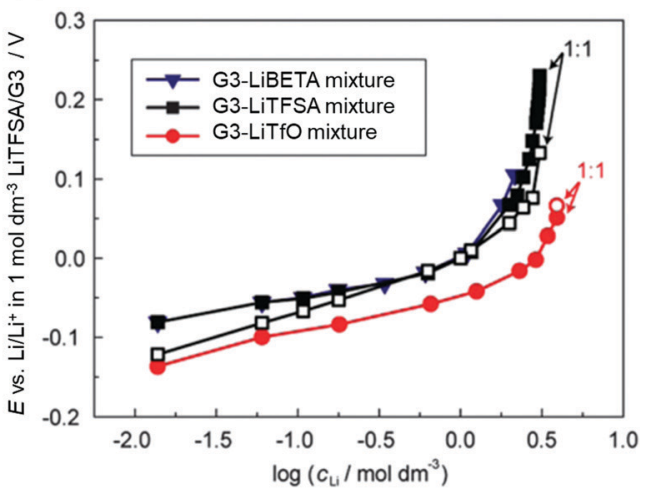

Fig. 3 Plots of the Li/Li+ electrode potential against a common logarithm of the Li salt concentration in (a) G4 (tetraglyme), G3 (triglyme), G2 (diglyme),

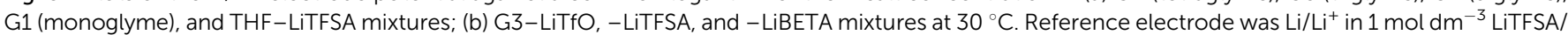
G3. (b) was reprinted with permission from ref. 59 Copyright 2015 PCCP Owner Societies.

$1 \mathrm{~mol} \mathrm{dm}^{-3}$ : THF (tetrahydrofuran) $>\mathrm{G} 1$ (monoglyme) $>\mathrm{G} 2$ (diglyme) $\sim \mathrm{G} 3$ (triglyme) $\sim \mathrm{G} 4$ (tetraglyme). This suggests that the values of $\Delta_{f} G^{\circ}\left(\left[\operatorname{Li}(\text { solvent })_{n}{ }^{+}\right]\right)$in the solvents serving as chelates decrease, and the bidentate ligand G1 and the multidentate ligands (G2, G3, and G4) further stabilise $\mathrm{Li}^{+}$as compared with the monodentate THF. ${ }^{61}$ It is well known that multidentate ligands (solvents) can form more stable complex ions owing to the chelate effect.

Fig. 4 shows the electrode potentials of Li metal electrode in $1 \mathrm{~mol} \mathrm{dm}{ }^{-3}$ LiTFSA solutions with various solvents. Gutmann's donor number (DN) is a good metric to determine the electron donating ability or Lewis basicity of a solvent. ${ }^{62,63}$ It is defined as the molar enthalpy of the reaction with $\mathrm{SbCl}_{5}$ as the standard acceptor. The electrode potential decreases on increasing the $\mathrm{DN}$ of the solvent, suggesting that a solvent with a higher DN stabilises $\mathrm{Li}^{+}$ions further decreasing the $\Delta_{f} G^{\circ}\left(\left[\operatorname{Li}(\text { solvent })_{n}{ }^{+}\right]\right)$.

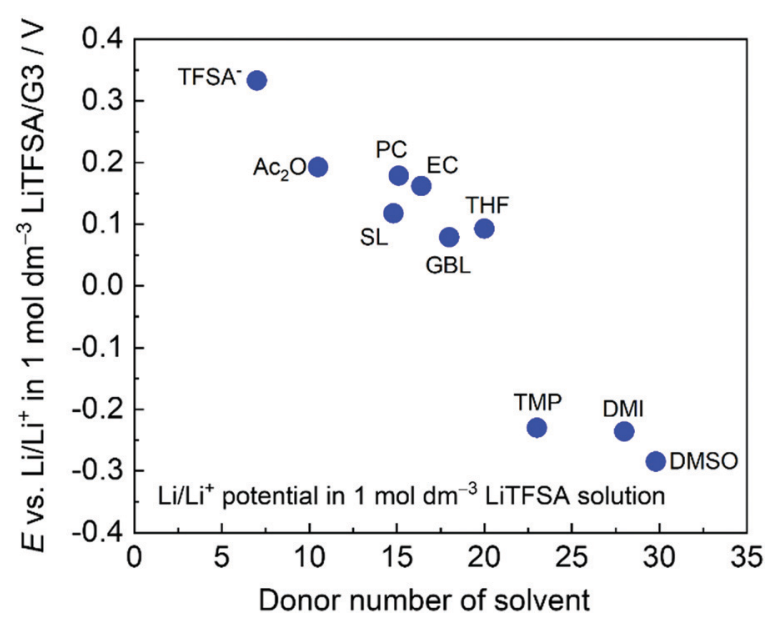

Fig. $4 \mathrm{Li} \mathrm{Li}^{+}$potential in $1 \mathrm{~mol} \mathrm{dm}{ }^{-3}$ LiTFSA in different solvents plotted against donor number of each solvent, measured at $30{ }^{\circ} \mathrm{C}$. TFSA ${ }^{-}$indicates $1 \mathrm{~mol} \mathrm{dm}{ }^{-3}$ LiTFSA/[P13][TFSA]. [P13][TFSA]: N-Methy- $N$-propylpyrrolidinium bis(trifluoromethanesulfonyl)amide, $\mathrm{Ac}_{2} \mathrm{O}$ : acetic anhydride, TMP: trimethyl phosphate, and DMI: 1,3-dimethyl-2-imidazolidinone. Reference electrode: $\mathrm{Li}^{\mathrm{Li}}{ }^{+}$in $1 \mathrm{~mol} \mathrm{dm}^{-3}$ LiTFSA/G3.

\subsection{Effects of anion species}

Weak Lewis basic anions, such as $\mathrm{BETA}^{-}, \mathrm{TFSA}^{-}$, and $\mathrm{PF}_{6}{ }^{-}$, interact with $\mathrm{Li}^{+}$ions weakly and dissociate easily. However, relatively strong Lewis basic anions, such as $\mathrm{TfO}^{-}$(trifluoromethanesulfonate), $\mathrm{NO}_{3}{ }^{-}$, and $\mathrm{TFA}^{-}$(trifluoroacetate), strongly interact with $\mathrm{Li}^{+}$ions, forming ion pairs and ionic aggregates in the electrolytes. Because the solvent and anions competitively coordinate to the $\mathrm{Li}^{+}$cations in the electrolyte solution, the strong Lewis basic anions remove the solvent molecules from the solvation shell of the $\mathrm{Li}^{+}$ions (Fig. 5), resulting in an increased solvent activity even at high salt concentrations. ${ }^{24,64,65}$ Henderson et al. reported the order of $\mathrm{Li}$ salts association in a glyme solution: $\mathrm{BPh}_{4}{ }^{-}<\mathrm{BETA}^{-} \sim \mathrm{TFSA}^{-} \sim \mathrm{SbF}_{6}{ }^{-} \sim \mathrm{AsF}_{6}{ }^{-}<\mathrm{PF}_{6}^{-} \sim \mathrm{I}^{-}<$ $\mathrm{SCN}^{-}<\mathrm{BF}_{4}^{-}<\mathrm{TfO}^{-}<\mathrm{Br}^{-}<\mathrm{NO}_{3}{ }^{-}<\mathrm{TFA}^{-18}$. It can be observed that the Li electrode potential decreases with increasing strength of Lewis bases (TFSA ${ }^{-}<$TfO $^{-}$) (Fig. 3b). Fig. 6 exhibits the Raman spectrum of $\left[\mathrm{Li}(\mathrm{G} 3)_{1}\right][\mathrm{TfO}]$, which indicates that most

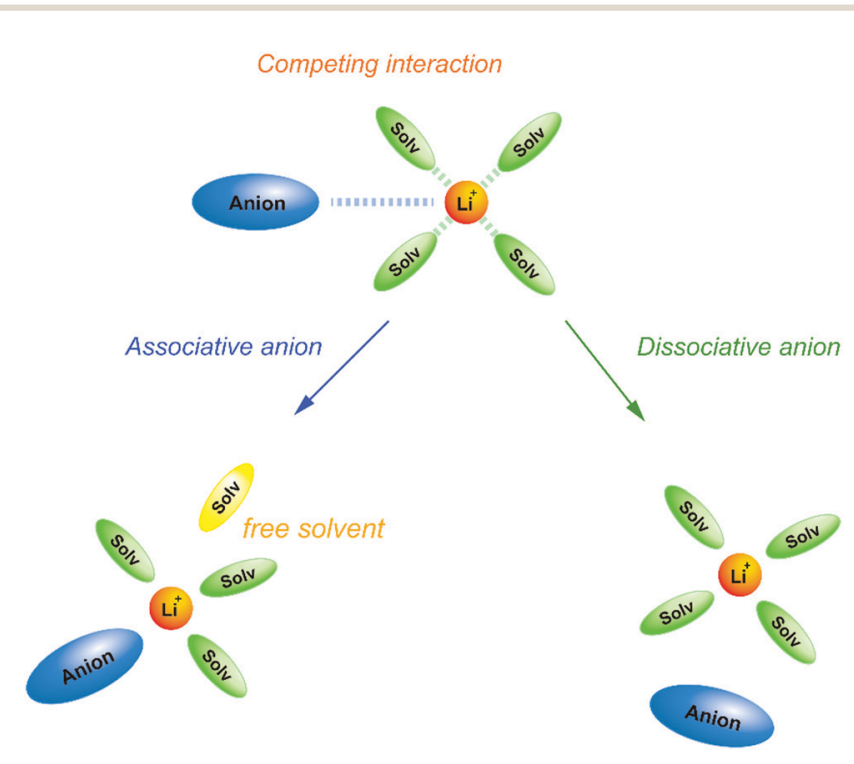

Fig. 5 Schematic illustration for the effect of Lewis basicity of anion on the solvation structure in highly concentrated electrolytes. 

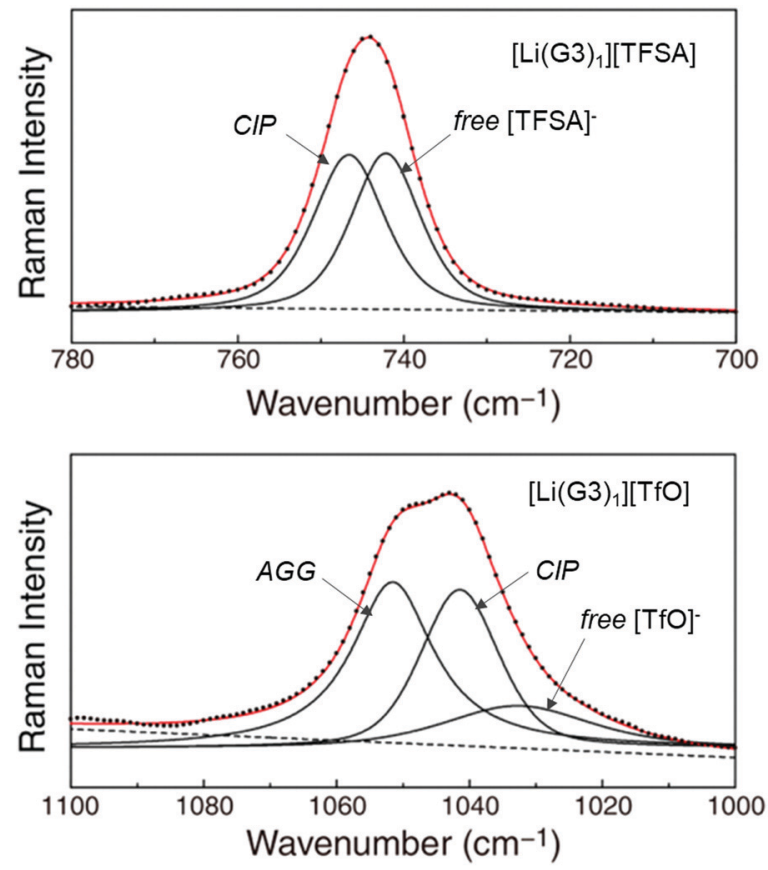

Fig. 6 Raman spectra of [Li(G3) $)_{1}\left[\right.$ TFSA] in the range $700-780 \mathrm{~cm}^{-1}$ (top, $\mathrm{CF}_{3}$ bending mode) and of $\left[\mathrm{Li}(\mathrm{G} 3)_{1}\right][\mathrm{TfO}]$ in the range $1000-1100 \mathrm{~cm}^{-1}$ (bottom, $\mathrm{SO}_{3}$ stretching mode) at $60{ }^{\circ} \mathrm{C}$. Reprinted with permission from ref. 58 Copyright 2014 American Chemical Society.

of the $\mathrm{TfO}^{-}$anions are coordinated to $\mathrm{Li}^{+}$ions to form a contact ion pair (CIP) and ionic aggregates (AGG), whereas the spectrum of $\left[\mathrm{Li}(\mathrm{G} 3)_{1}\right][\mathrm{TFSA}]$ indicates that half of the TFSA ${ }^{-}$exists as free anion (or solvent-separated ion pair, SSIP) because of its relatively weak Lewis basicity. ${ }^{58}$ Raman spectroscopic studies indicate that the fraction of the free solvent molecules increases with increasing anion Lewis basicity, ${ }^{59}$ which proves that strong Lewis bases strongly coordinate to $\mathrm{Li}^{+}$. In addition, the anion coordination may further stabilise $\mathrm{Li}^{+}$ions to form $\left[\mathrm{Li}(\text { solvent })_{n} \mathrm{X}\right]$ (X: anion), resulting in a lower value of $\Delta_{f} G^{\circ}\left(\left[\mathrm{Li}(\text { solvent })_{n} \mathrm{X}\right]\right)$ than $\Delta_{f} G^{\circ}\left(\left[\mathrm{Li}(\text { solvent })_{n}{ }^{+}\right]\right)$and a decreased electrode potential.

\subsection{Thermal stability}

The decrease in the solvent activity also contributes to the thermal stability of the electrolytes. For example, Fig. 7 exhibits the thermogravimetric analysis (TGA) for electrolyte solutions of NaFSA (FSA: bis(fluorosulfonyl)amide) dissolved in sulfolane (SL).$^{34}$ In case of pure SL, the weight loss starts at $\sim 100{ }^{\circ} \mathrm{C}$ because of evaporation. Similarly, in the solution with molar ratio of NaFSA/SL $=1 / 10$, the weight loss starts at approximately $100{ }^{\circ} \mathrm{C} . \mathrm{Na}^{+}$ion is solvated with SL, and FSA anion is scarcely coordinated to $\mathrm{Na}^{+}$in the NaFSA/SL $=1 / 10$ solution. Since the coordination number of $\mathrm{Na}^{+}$in organic solvents is generally $5-7,{ }^{35,66,67} \sim 50 \%$ of the SL molecules are free in the solution, and free SL can evaporate at lower temperature compared to coordinated SL. In contrast, the weight loss was not observed up to $250{ }^{\circ} \mathrm{C}$ at the molar ratio of $\mathrm{NaFSA} / \mathrm{SL}=1 / 1$. The population of free SL decreases with increasing the salt concentration in the electrolyte, ${ }^{34}$ and the thermal stability can be improved. ${ }^{21}$

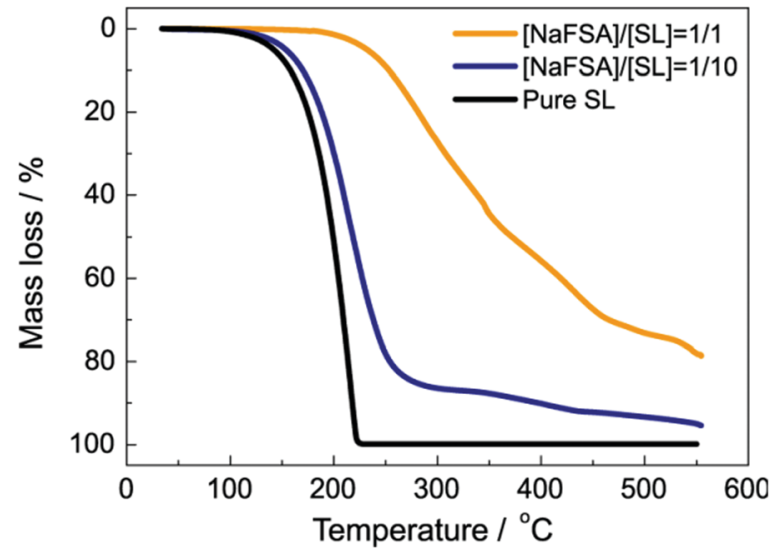

Fig. 7 Thermogravimetric curves of NaFSA/SL electrolytes at a heating rate of $10{ }^{\circ} \mathrm{C} \mathrm{min}^{-1}$. Reprinted with permission from ref. 34 Copyright 2020 American Chemical Society.

\section{Structure of solvates}

\subsection{Crystalline solvates}

Binary mixtures of Li salts and solvents can form stable crystalline solvates in stoichiometric ratios. In the crystalline solvates, the anions and solvent molecules that enclose the $\mathrm{Li}^{+}$ions are packed in long-range ordered crystalline lattices. Understanding the crystal structures of the solvates helps in estimating the $\mathrm{Li}^{+}$ coordination structures in the molten state. Henderson et al. investigated the structures of various crystalline solvates of Li salts. ${ }^{15,16,68-70}$ These solvates take a variety of forms such as solvent-separated ion pairs (SSIPs), contact ion pairs (CIPs), and aggregates (AGGs), where a single anion is coordinated to zero, one, and more than one $\mathrm{Li}^{+}$, respectively.

Earlier, we reported the crystal structures of sulfolane (SL) solvates of Li salts. ${ }^{31,39}$ Hereafter, the solvate composed of $\mathrm{Li}$ salt (LiX) and solvent with a molar ratio of $1: n$ is denoted as $\left[\mathrm{Li}(\text { solvent })_{n}\right][\mathrm{X}]$. Fig. 8a and $\mathrm{b}$ show the crystal structures of $\left[\mathrm{Li}(\mathrm{SL})_{1}\right]\left[\mathrm{BF}_{4}\right]$ and $\left[\mathrm{Li}(\mathrm{SL})_{2}\right]\left[\mathrm{ClO}_{4}\right]$ solvates analysed by singlecrystal X-ray crystallography. The coordination number of $\mathrm{Li}^{+}$ ions is 4 or 5 in the crystals, as shown in Fig. 8. In the crystal of the $\left[\mathrm{Li}(\mathrm{SL})_{1}\right]\left[\mathrm{BF}_{4}\right]$ solvate, all SL molecules bridge different $\mathrm{Li}^{+}$ ions, forming a polymeric network structure. In addition, each $\mathrm{BF}_{4}{ }^{-}$anion coordinates to more than one $\mathrm{Li}^{+}$ion (i.e. AGG coordination). In $\left[\mathrm{Li}(\mathrm{SL})_{2}\right]\left[\mathrm{ClO}_{4}\right]$ solvates, monodentate-type and bridging-type SL molecules coexist in a $1: 1$ ratio (Fig. 8b). Each $\mathrm{ClO}_{4}{ }^{-}$anion coordinates to $\mathrm{a} \mathrm{Li}^{+}$ion in a monodentate form (i.e. CIP coordination). Furthermore, it is to be noted that the solvent-bridged structure $\left(\mathrm{Li}^{+}-\mathrm{SL}-\mathrm{Li}^{+}\right)$is commonly formed in SL-based crystalline solvates. However, this unique structure is not a particular case for the solvates of cyclic SL. A similar bridging-type coordination is found in $\mathrm{Li}$ salt solvates of acyclic sulfones such as dimethyl sulfone. ${ }^{71}$ Similar solvent-bridged networks are also formed in crystalline solvates composed of Li salts and bridging ligands with multiple coordinating sites. In the single crystals of Li salt solvates of methyl pyruvate (MP) and methyl acetoacetate (MA), the ketone carbonyl oxygen and the ester carbonyl oxygen atoms bind to different $\mathrm{Li}^{+}$ions forming a solvent-bridged structure (Fig. 8c). ${ }^{72}$ 
(a) $\left[\mathrm{Li}(\mathrm{SL})_{1}\right]\left[\mathrm{BF}_{4}\right]$
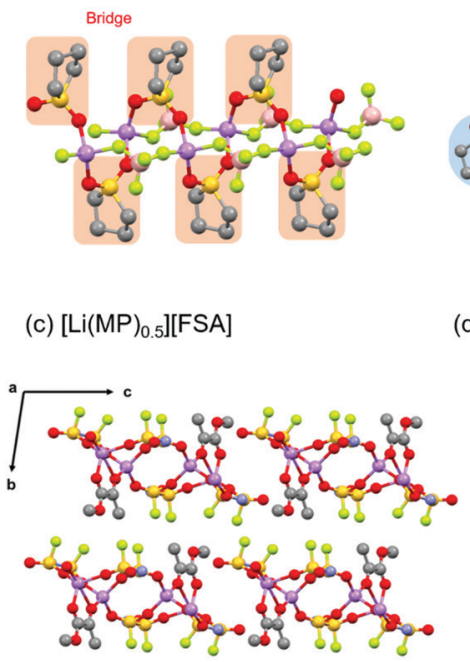

(c) $\left[\mathrm{Li}(\mathrm{MP})_{0.5}\right][\mathrm{FSA}]$ (b) $\left[\mathrm{Li}(\mathrm{SL})_{2}\right]\left[\mathrm{ClO}_{4}\right]$

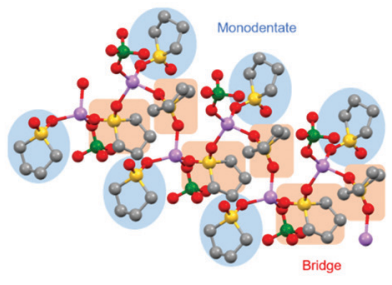

(d) $\left[\mathrm{Li}(\mathrm{SN})_{2}\right][\mathrm{FSA}]$

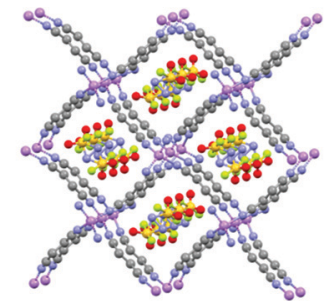

Fig. 8 Crystal structures of (a) $\left[\mathrm{Li}(\mathrm{SL})_{1}\right]\left[\mathrm{BF}_{4}\right]$ and (b) $\left[\mathrm{Li}(\mathrm{SL})_{2}\right]\left[\mathrm{ClO}_{4}\right]$ solvates. Reprinted with permission from ref. 31. Copyright 2018 American Chemical Society. (c) Crystal structure of [Li(MP) $0_{0.5}$ ] [FSA]. Reprinted with permission from ref. 72. Copyright 2019 PCCP Owner Societies. (d) Crystal structure of $\left[\mathrm{Li}(\mathrm{SN})_{2}\right][\mathrm{FSA}]$ solvate. Hydrogen atoms are not shown. Purple, $\mathrm{Li}$; red, O; grey, C; yellow, S; light green, F; pink, B; and green, $\mathrm{Cl}$.

Crystalline solvates composed of LiFSA and dinitriles, such as succinonitrile (SN), glutaronitrile (GN), and adiponitrile (ADN), have unique mesh structures, in which all the dinitrile molecules link to different $\mathrm{Li}^{+}$ions, whereas $\mathrm{FSA}^{-}$anions exist in the vacant sites and do not coordinate to $\mathrm{Li}^{+}$ions (Fig. 8d). ${ }^{73}$ In addition to the Li-based systems, the crystalline solvates of Na salts have also been studied. ${ }^{34,35}$ The coordination number of $\mathrm{Na}^{+}$in these crystalline solvates is 6 , which is larger than that of $\mathrm{Li}^{+}$, because of its larger ionic radius.

\subsection{Liquid structure of molten solvates}

Raman spectroscopy was performed to study the coordination structures of the solvates in the molten/liquid state. The Raman spectra of the solvates in the liquid and solid states were compared. Fig. 9a shows the Raman spectra for pure SL and the solid and liquid states of $\left[\mathrm{Li}(\mathrm{SL})_{2}\right]\left[\mathrm{ClO}_{4}\right]$ solvate in the range $550-600 \mathrm{~cm}^{-1}$. The pure SL shows a peak at $568 \mathrm{~cm}^{-1}$ assigned to the scissoring vibration of $\mathrm{SL} ;{ }^{74}$ on complexation with $\mathrm{Li}^{+}$ ions, this peak shifts to a higher wavenumber. The solid state $\left[\mathrm{Li}(\mathrm{SL})_{2}\right]\left[\mathrm{ClO}_{4}\right]$ solvate exhibits two peaks centred at 571 and $580 \mathrm{~cm}^{-1}$. In the crystal structure of the $\left[\mathrm{Li}(\mathrm{SL})_{2}\right]\left[\mathrm{ClO}_{4}\right]$ solvate (Fig. 8b), half of the SL molecules act as monodentate ligands for the $\mathrm{Li}^{+}$ion, and the remaining half act as bridging ligands. Therefore, the two peaks of SL at 571 and $580 \mathrm{~cm}^{-1}$ in the $\left[\mathrm{Li}(\mathrm{SL})_{2}\right]\left[\mathrm{ClO}_{4}\right]$ crystal can be assigned to monodentate and bridging types of SL molecules, respectively. Upon melting, the integral intensity of the lower wavenumber peak increases compared with that of the higher wavenumber peak, suggesting that a certain amount of the bridging type SL molecules changes to monodentate-type molecules with a solid-to-liquid phase transition. However, the broadened peak of the liquid state $\left[\mathrm{Li}(\mathrm{SL})_{2}\right]\left[\mathrm{ClO}_{4}\right]$ contains a higher wavenumber peak for the bridging type SL. This suggests that the solvent-bridged structures of $\mathrm{Li}^{+}-\mathrm{SL}-\mathrm{Li}^{+}$observed in the crystal (Fig. 8a and b) are partially maintained even in the liquid state.

Fig. 9b shows the Raman spectra for the Cl-O symmetric stretch vibration mode of $\mathrm{ClO}_{4}{ }^{-}$in the $\left[\mathrm{Li}(\mathrm{SL})_{2}\right]\left[\mathrm{ClO}_{4}\right]$ solvate. The crystal of $\left[\mathrm{Li}(\mathrm{SL})_{2}\right]\left[\mathrm{ClO}_{4}\right]$ shows a sharp Raman band at $934 \mathrm{~cm}^{-1}$, which is assigned to the CIP coordination where the $\mathrm{ClO}_{4}{ }^{-}$anion is coordinated to a single $\mathrm{Li}^{+}$ion. Upon melting, the $\mathrm{ClO}_{4}{ }^{-}$peak shifts to a higher wavenumber, suggesting that a $\mathrm{ClO}_{4}{ }^{-}$anion is coordinated to multiple $\mathrm{Li}^{+}$ions in the molten $\left[\mathrm{Li}(\mathrm{SL})_{2}\right]\left[\mathrm{ClO}_{4}\right]$ solvate. ${ }^{16}$ This is because the number of bridging type SL decreases with the melting of $\left[\mathrm{Li}(\mathrm{SL})_{2}\right]\left[\mathrm{ClO}_{4}\right]$ crystal (vide supra), and thus, $\mathrm{ClO}_{4}{ }^{-}$anions should be involved in the coordination of more than one $\mathrm{Li}^{+}$ion (i.e. AGG coordination) to satisfy the preferred coordination number of $\mathrm{Li}^{+}$.

The salt concentration significantly affects the liquid structure of the electrolytes. Fig. 9c exhibits the Raman spectra in the wavenumber range $700-800 \mathrm{~cm}^{-1}$ for LiTFSA/SL binary mixtures with different solvent/Li salt molar ratios $(x)$, corresponding to the $\mathrm{S}-\mathrm{N}$ stretching vibration mode of TFSA anions. $^{75,76}$ The peak in this region is sensitive to ion association and is often utilised to characterise different forms of $\mathrm{Li}^{+}-\mathrm{TFSA}^{-}$
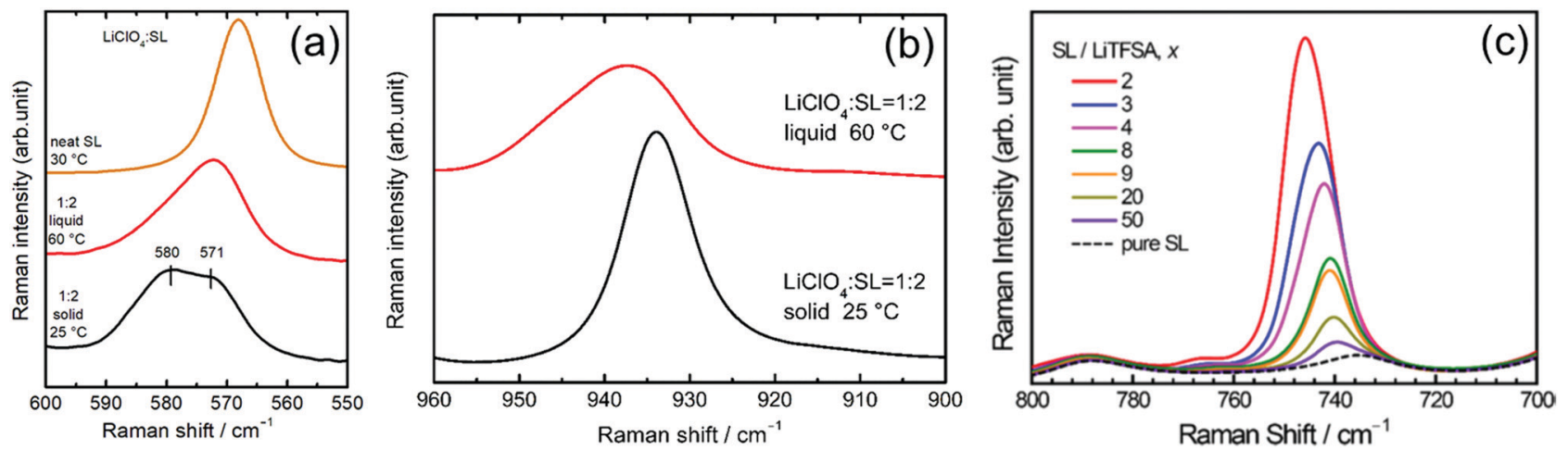

Fig. 9 Raman spectra of (a) scissoring mode of the $\mathrm{SO}_{2}$ group of $\mathrm{SL}$ and (b) $\mathrm{Cl}-\mathrm{O}$ symmetric stretch vibration mode of $\mathrm{ClO}_{4}{ }^{-}$in the $\left[\mathrm{Li}(\mathrm{SL})_{2}\right]\left[\mathrm{ClO}{ }_{4}\right]$ solvate. Reprinted with permission from ref. 31 Copyright 2018 American Chemical Society. (c) Raman spectra of the S-N stretching vibration mode of TFSA $^{-}$anion in the LiTFSA/SL binary mixtures. Reprinted with permission from ref. 39 Copyright 2019 American Chemical Society. 
coordination. ${ }^{69,77,78}$ In the dilute region with $x \geq 20$, the Raman bands of TFSA ${ }^{-}$appear at $740 \mathrm{~cm}^{-1}$, corresponding to SSIP in which TFSA $^{-}$anions are uncoordinated. ${ }^{69,78}$ The peak gradually shifts to a higher wavenumber with decreasing $x$ (i.e. increasing salt concentration), indicating the complexation of $\mathrm{Li}^{+}$and $\mathrm{TFSA}^{-}$anions in the mixture. In the high salt concentration region with $x<4$, the Raman peak position exceeds $744 \mathrm{~cm}^{-1}$, suggesting the formation of the CIP and AGG solvates in which the TFSA $^{-}$anions are coordinated to one or more $\mathrm{Li}^{+}$ions. ${ }^{69,78,79}$ These results indicate that when the $x$ is lower than 4 (the preferred coordination number of $\mathrm{Li}^{+}$), anions participate in the coordination of $\mathrm{Li}^{+}$ions to form CIPs and AGGs. Similar ion pairs and ionic aggregates are also formed in the solvent-deficient electrolyte solutions incorporating other anions and alkaline metal ions. ${ }^{78,80-84}$

\section{Transport properties}

\subsection{Self-diffusion coefficients}

The $\mathrm{Li}^{+}$transport properties of liquid electrolytes are assumed to be one of the most significant parameters for improving the battery performance. In particular, the ionic conductivity of the electrolytes has been linked to the rapid charge and discharge ability. As we described in Section 1, the overall ionic conductivity $\left(\sigma_{\text {ion }}\right)$ depends on both the number of carriers and carrier mobility. Hence, the total ionic conductivity reaches a maximum value at a salt concentration of $\sim 1 \mathrm{~mol} \mathrm{dm}^{-3}$ and drastically decreases upon further increase in the salt concentration to the concentrated region. ${ }^{31,61,72,73}$ The $\sigma_{\text {ion }}$ values of some molten solvate electrolytes at $30{ }^{\circ} \mathrm{C}$ are listed in Table 1 . The molten solvate electrolytes exhibit approximately one or two orders of magnitude lower conductivity than that of a conventional organic electrolyte ( $1 \mathrm{~mol} \mathrm{dm}^{-3} \mathrm{LiPF}_{6}$ in $\mathrm{EC} / \mathrm{DMC}(50: 50 \mathrm{wt} \%)$ ) due to significantly high viscosity of the molten solvate electrolytes.

In addition to the ionic conductivity, the self-diffusion coefficients of Li cations $\left(D_{\mathrm{Li}}\right)$, anions $\left(D_{\text {anion }}\right)$, and solvents $\left(D_{\text {sol }}\right)$, which are obtained from pulse field gradient - nuclear magnetic resonance (PFG-NMR) spectroscopy, have been studied in liquid electrolytes. ${ }^{88}$ In the case of conventional electrolyte solutions containing ca. $1 \mathrm{~mol} \mathrm{dm}^{-3} \mathrm{Li}$ salt, the order of diffusion coefficients is as follows: $D_{\mathrm{Li}}<D_{\text {anion }}<D_{\text {sol }}{ }^{88}$ This is because $\mathrm{Li}^{+}$ ions are solvated in the solution. According to the Stokes-Einstein equation, the diffusion coefficient $D$ is related to the viscosity $(\eta)$

Table 1 Viscosity $(\eta)$, ion conductivity $\left(\sigma_{\text {ion }}\right)$, transference numbers of $\mathrm{Li}$ ion evaluated by PFG - NMR method $\left(t_{\mathrm{Li}}^{\mathrm{NMR}}\right)$ and potentiostatic polarisation method $\left(t_{\mathrm{Li}}^{\mathrm{PP}}\right)$ for electrolytes at $30^{\circ} \mathrm{C}$

\begin{tabular}{|c|c|c|c|c|}
\hline Sample & $\eta / \mathrm{mPa} \mathrm{s}$ & $\sigma / \mathrm{mS} \mathrm{cm}^{-1}$ & $t_{\mathrm{Li}}^{\mathrm{NMR}}$ & $t_{\mathrm{Li}}^{\mathrm{PP}}$ \\
\hline $\begin{array}{l}1 \mathrm{~mol} \mathrm{dm}^{-3} \mathrm{LiPF}_{6} \text { in } \\
\text { EC/DMC }(50: 50 \mathrm{wt} \%)^{a}\end{array}$ & 3.77 & 13 & 0.41 & 0.07 \\
\hline$\left[\mathrm{Li}(\mathrm{G} 1)_{2}\right][\mathrm{TFSA}]^{b}$ & 33.9 & 3.7 & 0.54 & 0.35 \\
\hline$\left[\mathrm{Li}(\mathrm{SL})_{2}\right][\mathrm{TFSA}]^{b}$ & 622 & 0.42 & 0.61 & 0.68 \\
\hline$\left[\mathrm{Li}(\mathrm{SL})_{2}\right]\left[\mathrm{BF}_{4}\right]$ & 743 & 0.61 & 0.61 & 0.82 \\
\hline$\left[\mathrm{Li}(\mathrm{SN})_{0.8}\right][\mathrm{FSA}]^{c}$ & 3140 & 0.26 & 0.62 & 0.74 \\
\hline$\left[\mathrm{Li}(\mathrm{GN})_{1.5}\right][\mathrm{TFSA}]^{d}$ & 1420 & 0.21 & 0.56 & 0.74 \\
\hline
\end{tabular}

${ }^{a}$ Ref. 85 and 86. ${ }^{b}$ Ref. 87. ${ }^{c}$ Ref. 73. ${ }^{d}$ Ref. 79. and the hydrodynamic radius $(r)$ as follows: $D=k_{\mathrm{B}} T / 6 \pi r \eta$ (for spherical particles) where $k_{\mathrm{B}}$ is the Boltzmann constant. The hydrodynamic radius of solvated $\mathrm{Li}^{+}$ion $\left(\left[\mathrm{Li}(\text { solvent })_{n}\right]^{+}\right)$is larger than that of anion and free solvent, and $\mathrm{Li}^{+}$ion mainly diffuses in the form of solvated cation.

The diffusivity ratio of the solvent and $\mathrm{Li}\left(D_{\mathrm{sol}} / D_{\mathrm{Li}}\right)$ is a particularly useful metric to evaluate the extent to which the self-diffusion of $\mathrm{Li}^{+}$ion is decoupled from that of the solvent. Fig. 10a exhibits the plot of $D_{\mathrm{sol}} / D_{\mathrm{Li}}$ versus the Li salt concentration for ether-, ${ }^{61}$ sulfone- ${ }^{31}$ keto ester-, ${ }^{72}$ and nitrile- ${ }^{73}$ based molten Li salt solvates. The electrolytes with concentrations below $3 \mathrm{~mol} \mathrm{dm}^{-3}$ show $D_{\mathrm{sol}} / D_{\mathrm{Li}}>1$ indicating that, on average, Li ions diffuse slower than the solvent molecules, similar to the conventional liquid electrolytes with $\sim 1 \mathrm{~mol} \mathrm{dm}^{-3}$ salt concentration (vide supra). By contrast, at

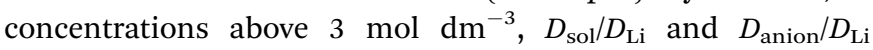
(Fig. 10b) are below unity, indicating that Li ions diffuse most rapidly among the components, except for the ether-based molten Li salt solvates. The main reason for the fastest diffusion of $\mathrm{Li}$ ions among the components at high concentrations $>3 \mathrm{~mol} \mathrm{dm}^{-3}$ can likely be attributed to the Li ion hopping/ exchange mechanism (Fig. 11) through the unique $\mathrm{Li}$ ion coordination structures mentioned in the previous section. For instance, in $\left[\mathrm{Li}(\mathrm{SL})_{2}\right]\left[\mathrm{BF}_{4}\right]$, Li ions form ion aggregates such as $\left[\mathrm{Li}^{+}{ }_{x}(\mathrm{SL})_{y}\left[\mathrm{BF}_{4}\right]_{z}^{-}\right]^{(x-z)}$ and/or a solvent-bridged structure $\left(-\mathrm{Li}^{+}-\mathrm{SL}-\right.$ $\left.\mathrm{Li}^{+}-\mathrm{SL}-\right)$ in the liquid states. ${ }^{31}$ The keto ester- and nitrile-based molten Li salt solvates also have similar solvent-shared, polymeric $\mathrm{Li}$ ion coordination structures. ${ }^{72,73,79}$ A single $\mathrm{SN}$ molecule has two different coordination sites to which two different Li ions can coordinate resulting in the formation of solvent-bridged network structures $\left(\mathrm{Li}^{+}-\mathrm{SN}-\mathrm{Li}^{+}\right)$. In these cases, solvents and anions serve as a framework for Li-ion conduction paths, which regulate the diffusion of the solvent and anions. Therefore, $\mathrm{Li}$ ions are considered to be carried through percolating ion aggregates and solvent-bridged structures via unique $\mathrm{Li}$ ion hopping/exchange mechanism.

In the case of ether-based molten solvate $\left[\mathrm{Li}(\mathrm{G1})_{2}\right][\mathrm{TFSA}], \mathrm{G} 1$ molecules are assumed to coordinate to $\mathrm{Li}$ ions in a bidentate manner along with the formation of AGGs and/or CIPs between $\mathrm{Li}^{+}-[\mathrm{TFSA}]^{-}{ }^{17}$ However, Li ions solvated with G1 molecules exhibit relatively low stabilisation energy, ${ }^{89}$ which enables $\mathrm{Li}$ ions to exchange the $\mathrm{G} 1$ ligand with other solvated $\mathrm{Li}$ ions and/ or to leave the ligand as "free" G1. Therefore, G1 molecules diffuse more rapidly than $\mathrm{Li}$ ions (resulting in $D_{\mathrm{sol}} / D_{\mathrm{Li}}>1$ ) even at high concentrations.

\subsection{Transference number}

In addition to ionic conductivity, the $\mathrm{Li}^{+}$transference number has been considered as another significant parameter of electrolytes affecting the battery performance. ${ }^{90-92}$ Various methods have been proposed for the estimation of the transference number: electrophoretic NMR, ${ }^{93}$ PFG-NMR, ${ }^{24,88}$ Hittorf method, ${ }^{94}$ potentiostatic polarisation $\operatorname{method}^{95,96}$ and very-lowfrequency electrochemical impedance spectroscopy (EIS). ${ }^{85}$ PFG-NMR method $\left(t_{\mathrm{Li}}^{\mathrm{NMR}}\right)$, based on the Nernst-Einstein equation, has been extensively studied for $\mathrm{Li}$ ion conducting 

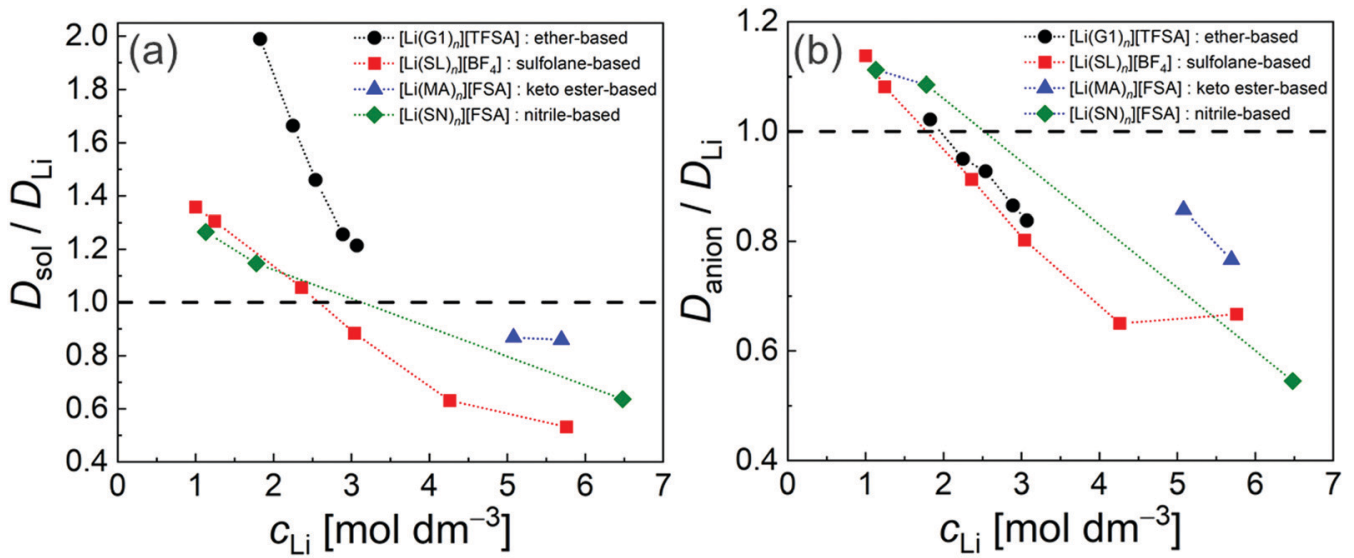

Fig. 10 Diffusivity ratio (a) $D_{\mathrm{sol}} / D_{\mathrm{Li}}$ and (b) $D_{\text {anion }} / D_{\mathrm{Li}}$ of ether-, sulfolane-, keto ester-, and nitrile-based electrolytes at $30{ }^{\circ} \mathrm{C}$. ([Li(G1) $\left.)_{n}\right][T F S A]: n=1.8,2$, 2.5, 3, and 4; [Li(SL) $\left.{ }_{n}\right]\left[\mathrm{BF}_{4}\right]: n=1.35,2,3,4,8$, and 10; [Li(MA) $\left.n\right][\mathrm{FSA}]: n=0.8$ and 1 ; and [Li(SN) $\left.n\right][F S A]: n=0.8,6$ and 10). Data were collected from ref. 31, 61,72 and 73 and replotted.

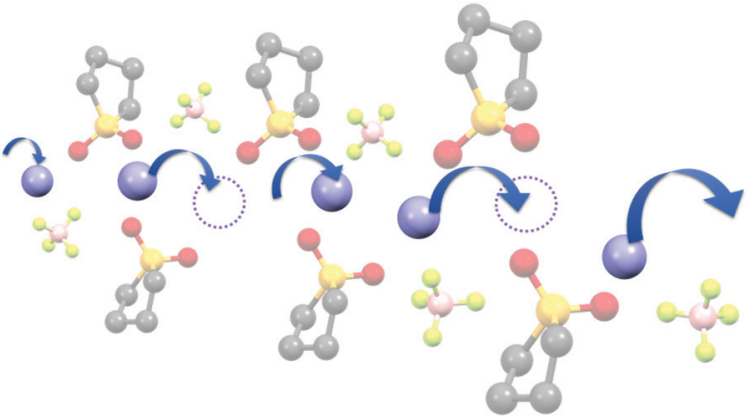

Fig. 11 Schematic image of the Li ion hopping/exchange conduction of molten SL solvates of Li salts. Reprinted with permission from ref. 31 Copyright 2018 American Chemical Society.

liquid electrolytest $t_{\mathrm{Li}}^{\mathrm{NMR}} \cdot t_{\mathrm{Li}}^{\mathrm{NMR}}$ is evaluated as the ratio of the selfdiffusion coefficients of ion species: $t_{\mathrm{Li}}^{\mathrm{NMR}}=D_{\mathrm{Li}} /\left(D_{\mathrm{Li}}+D_{\text {anion }}\right)$. However, $t_{\mathrm{Li}}^{\mathrm{NMR}}$ does not reflect the true $\mathrm{Li}^{+}$transference number for highly concentrated electrolytes with strong ion interactions and correlations because this method is based on ideal electrolyte solutions where ions are completely dissociated and move independently.

An electrochemical method using a Li metal symmetric cell has often been applied to estimate the transference number. This transference number $\left(t_{\mathrm{Li}}^{\mathrm{PP}}\right)$ is obtained by combining the potentiostatic polarisation with EIS and is defined as follows: ${ }^{95,96}$

$$
t_{\mathrm{Li}}^{\mathrm{PP}}=\frac{I_{\mathrm{SS}}\left(V_{\mathrm{DC}}-I_{\mathrm{Ohm}} R_{i, 0}\right)}{I_{\mathrm{Ohm}}\left(V_{\mathrm{DC}}-I_{\mathrm{SS}} R_{i, \mathrm{SS}}\right)}
$$

where $V_{\mathrm{DC}}$ is the constant applied voltage, $I_{\mathrm{Ohm}}\left(=V_{\mathrm{DC}} /\left(R_{\mathrm{bulk}}+\right.\right.$ $\left.\left.R_{i, 0}\right)\right), I_{\mathrm{SS}}$ are the initial and stationary state currents, and $R_{i, 0}$ and $R_{i, \mathrm{Ss}}$ are the initial and stationary state interfacial resistance values, respectively. ${ }^{97}$ The $t_{\mathrm{Li}}^{\mathrm{PP}}$ shows the true transference number only when there are no ionic interactions in the electrolytes (i.e. ideal electrolyte). Balsara et al. suggested that $t_{\mathrm{Li}}^{\mathrm{PP}}$ simply shows the "current fraction" carried by Li ions in non-ideal electrolytes. ${ }^{97}$ However, $t_{\mathrm{Li}}^{\mathrm{PP}}$ can be measured easily and is used to examine the actual Li-ion transport properties in electrochemical cells, such as Li-ion batteries, which include both migration and diffusion effects (under anion-blocking conditions). A high $t_{\mathrm{Li}}^{\mathrm{PP}}$ suggests that the concentration polarisation of electrolytes can be alleviated in the electrochemical cells.

The two experimental Li transference numbers $\left(t_{\mathrm{Li}}^{\mathrm{NMR}}\right.$ and $\left.t_{\mathrm{Li}}^{\mathrm{PP}}\right)$ of ether-, sulfolane-, and nitrile-based molten Li salt solvates are shown in Table 1. The values of those numbers for conventional organic electrolyte, $1 \mathrm{~mol} \mathrm{dm}^{-3} \mathrm{LiPF}_{6}$ in EC/DMC, are reported as 0.41 for $t_{\mathrm{Li}}^{\mathrm{NMR} 86}$ and 0.07 for $t_{\mathrm{Li}}^{\mathrm{PP}}{ }^{85}$ Apparently, the molten Li salt solvates are prone to exhibiting higher values compared with that of conventional organic electrolytes. The $t_{\mathrm{Li}}^{\mathrm{PP}}$ values of the SL- and nitrile-based molten Li salt solvates with unique Li ion diffusion behaviour are much higher than those of the ether-based $\left[\mathrm{Li}(\mathrm{G} 1)_{2}\right][\mathrm{TFSA}]$. It has been suggested that the solvent-bridged $\mathrm{Li}$ ion coordination structure exerts a strong impact on the enhancement of $t_{\mathrm{Li}}^{\mathrm{PP}}$ and $t_{\mathrm{Li}}^{\mathrm{NMR}}$ values. The SLand GBL-based molten Na salt solvates also exhibit high $t_{\mathrm{Na}}^{\mathrm{PP}}$ values of 0.81 for $\left[\mathrm{Na}(\mathrm{SL})_{1}\right][\mathrm{FSA}]^{34}$ and 0.84 for $\left[\mathrm{Na}(\mathrm{GBL})_{1}\right][\mathrm{FSA}]^{35}$ The two molten Na salt solvates have ligand-bridged structures $\left(\mathrm{Na}^{+}-\right.$(solvent or $\left.\left.\mathrm{FSA}\right)-\mathrm{Na}^{+}\right)$resembling the solvent-bridged structure confirmed in the molten Li salt solvates, which enables the dynamic ligand-exchange conduction of $\mathrm{Na}^{+}$. All these molten solvates maintain a unique solvent-bridged structure consisting of solvent and anions concurrently with the formation of CIPs and/or AGGs therein. Therefore, the motion of smaller $\mathrm{Li}$ (or Na) ions via dynamic ligand-exchange conduction is not relatively regulated compared with those of the solvent molecules and anions in the ion coordination, which results in the improvement of $t_{\mathrm{Li}}^{\mathrm{pP}}\left(\right.$ or $\left.t_{\mathrm{Na}}^{\mathrm{PP}}\right)$.

The relationship between the Li ion-anion interactions and the $t_{\mathrm{Li}}^{\mathrm{PP}}$ values for SL-based electrolytes was also studied. As shown in Table 1, $\left[\mathrm{Li}(\mathrm{SL})_{2}\right]\left[\mathrm{BF}_{4}\right]$ has a larger $t_{\mathrm{Li}}^{\mathrm{PP}}$ value $(0.82)$ than $\left[\mathrm{Li}(\mathrm{SL})_{2}\right][\mathrm{TFSA}](0.68)$. $\left[\mathrm{Li}(\mathrm{SL})_{3}\right]\left[\mathrm{ClO}_{4}\right]$ shows a similar $t_{\mathrm{Li}}^{\mathrm{PP}}$ value $(0.65)$ to that of $\left[\mathrm{Li}(\mathrm{SL})_{2}\right][\mathrm{TFSA}]$. The apparent dissociation degree of $\mathrm{LiBF}_{4}$ is known to be smaller than that of LiTFSA and 
$\mathrm{LiClO}_{4}$ in organic solvents. ${ }^{18}$ Therefore, AGGs are more prominent in $\left[\mathrm{Li}(\mathrm{SL})_{2}\right]\left[\mathrm{BF}_{4}\right]$ than in $\left[\mathrm{Li}(\mathrm{SL})_{2}\right][\mathrm{TFSA}]$ and $\left[\mathrm{Li}(\mathrm{SL})_{3}\right]\left[\mathrm{ClO}_{4}\right]$. Similarly, it was found that $t_{\mathrm{Li}}^{\mathrm{PP}}$ increases with more associative anions in glyme-based molten Li salt solvates. ${ }^{98}$ The stronger Li ion-anion interaction forming more-pronounced AGG networks in $\left[\mathrm{Li}(\mathrm{SL})_{2}\right]\left[\mathrm{BF}_{4}\right]$ will positively contribute to the enhancement of $t_{\mathrm{Li}}^{\mathrm{PP}}$ in addition to the solvent-bridged structures.

\subsection{Dynamic ion correlations}

The Li-ion transport in the concentrated electrolytes has been studied in more detail in the light of the dynamic ion correlations. Woolf and Harris systematically evaluated the dynamic ion correlations in aqueous electrolyte solutions by introducing velocity cross-correlation functions. ${ }^{99,100}$ Regarding solid polymer electrolytes, Balsara and Newman introduced Stefan-Maxwell diffusion coefficients. ${ }^{97,101,102}$ For non-aqueous liquid electrolyte solutions, Roling and Bedrov's groups investigated the dynamic ion correlations based on Onsager's linear irreversible thermodynamics and evaluated the Onsager transport coefficients for the glyme-based molten solvates of LiTFSA. ${ }^{85,103}$

In the Onsager transport formalism, the ionic conductivity $\sigma_{\text {ion }}$ is written as follows:

$$
\sigma_{\text {ion }}=\sigma_{++}+\sigma_{--}-2 \sigma_{+-}
$$

where $\sigma_{++}, \sigma_{--}$, and $\sigma_{+-}$are the Onsager transport coefficients. The Onsager coefficients $\sigma_{++}$and $\sigma_{--}$can be divided into selfterms and distinct terms, and eqn (6) can then be written as follows:

$$
\sigma_{\text {ion }}=\sigma_{+}^{\text {self }}+\sigma_{++}^{\text {distinct }}+\sigma_{-}^{\text {self }}+\sigma_{--}^{\text {distinct }}-2 \sigma_{+-}
$$

The self-terms, $\sigma_{+}^{\text {self }}$ and $\sigma_{-}^{\text {self }}$, are related to the self-diffusion coefficients of cation and anion, respectively, via the NernstEinstein equation. The distinct terms, $\sigma_{++}^{\text {distinct }}, \sigma_{--}^{\text {distinct }}$, and $\sigma_{+-}$, represent the dynamic cation-cation, anion-anion, and cationanion ion correlations, respectively. The signs on these distinct terms indicate the dynamic ion motions; the correlated ion motion occurs when it is positive, whereas the anti-correlated motion is dominant when the sign is negative. The noncorrelated ion motions expected in ideal electrolyte solutions are represented by the zero values of these coefficients. Based on eqn (7), the correlated motion of ions with the same sign positively contributes to the overall ionic conductivity, whereas that of the cation-anion correlation $\left(\sigma_{+-}\right)$contributes negatively.

We evaluated the Onsager coefficients for molten Li salt solvates to elucidate the ion correlations. ${ }^{87,98}$ The values of $\sigma_{+}^{\text {self }}$ and $\sigma_{-}^{\text {self }}$ were calculated from the self-diffusion coefficients of ions. The values of $\sigma_{++}, \sigma_{--}$, and $\sigma_{+-}$were estimated from the experimentally obtained quantities: ionic conductivity, transference number $\left(t_{\mathrm{Li}}^{\mathrm{PP}}\right)$, salt diffusion coefficients, and the slope of the concentration dependence of the concentration cell potentials. The normalised Onsager transport coefficients for the molten solvate electrolytes are shown in Fig. 12.

As shown in Fig. 12a, the ether-based Li salt molten solvate, $\left[\mathrm{Li}(\mathrm{G} 1)_{2}\right][\mathrm{TFSA}]$, shows negative values for all cross-correlation coefficients $\left(\sigma_{++}^{\text {distinct }} / \sigma_{\text {ion }}, \sigma_{--}^{\text {distinct }} / \sigma_{\text {ion }}\right.$, and $\left.\sigma_{+-} / \sigma_{\text {ion }}\right)$, suggesting that the ion motions are anti-correlated. Interestingly, in $\left[\mathrm{Li}(\mathrm{SL})_{2}\right][\mathrm{TFSA}]$ and $\left[\mathrm{Li}(\mathrm{SL})_{2}\right]\left[\mathrm{BF}_{4}\right]$, the dynamic cation - cation $\left(\sigma_{++}^{\text {distinct }} / \sigma_{\text {ion }}\right)$ cross-correlations are less anti-correlated and the dynamic cation - anion $\left(\sigma_{+-} / \sigma_{\text {ion }}\right)$ cross-correlations are nearly non-correlated (Fig. 12b and c) even at almost the same salt concentration as that of $\left[\mathrm{Li}(\mathrm{G} 1)_{2}\right][\mathrm{TFSA}]$. It is likely that $\mathrm{Li}$ ion hopping/exchange conduction is reflected by the nearly noncorrelated ion motions, which further contributes to the higher $t_{\mathrm{Li}}^{\mathrm{PP}}$ for the SL-based electrolytes. The $\sigma_{+-} / \sigma_{\text {ion }}$ exhibits a slightly negative value for $\left[\mathrm{Li}(\mathrm{SL})_{2}\right][\mathrm{TFSA}]$; however, it shifts to nearly zero for $\left[\mathrm{Li}(\mathrm{SL})_{2}\right]\left[\mathrm{BF}_{4}\right]$. This supports the more pronounced association of $\mathrm{LiBF}_{4}$ than that of LiTFSA in the SL-based molten solvates. Therefore, the developed AGG networks ${ }^{31}$ accompanied by the bridged structure are responsible for the considerably high $t_{\mathrm{Li}}^{\mathrm{PP}}$ in $\left[\mathrm{Li}(\mathrm{SL})_{2}\right]\left[\mathrm{BF}_{4}\right]$.

Considering the aforementioned results, unique SL-bridged structures and continuous $\mathrm{Li}^{+}$ordering structures in AGG offset the anti-correlations of cation-cation and cation-anion motions, resulting in the large contribution of Li ions to the overall ionic conductivity.

\section{Electrochemistry}

\subsection{Li metal electrode}

Highly concentrated electrolytes have various advantages in battery applications. These advantages are attributed to the
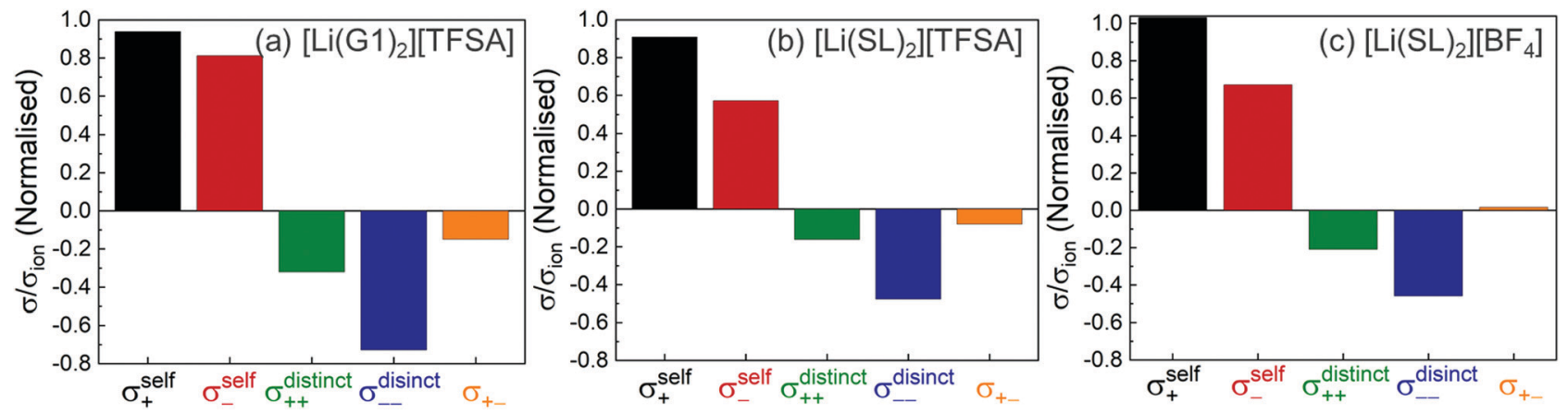

Fig. 12 Normalised Onsager transport coefficients $\left.\left(\sigma_{+}^{\text {self }} / \sigma_{\text {ion }}, \sigma_{-}^{\text {self }} / \sigma_{\text {ion, }}, \sigma_{++}^{\text {distinct }} / \sigma_{\text {ion, }}, \sigma_{--}^{\text {distinct }} / \sigma_{\text {ion, }} \text { and } \sigma_{+-} / \sigma_{\text {ion }}: \text { left to right) of (a) [Li(G1) }\right)_{2}\right][$ TFSA], (b) $\left[\mathrm{Li}(\mathrm{SL})_{2}\right][\mathrm{TFSA}]$, and (c) $\left[\mathrm{Li}\left(\mathrm{SL}_{2}\right]\left[\mathrm{BF}_{4}\right]\right.$. The graphs (a) and (b) are reprinted with permission from ref. 87. Copyright 2020 PCCP Owner Societies. 
peculiar liquid structures of the highly concentrated electrolytes. Here, we show how the activities of the solvated metal ions and free solvent molecules in the electrolyte affect the electrochemical properties of $\mathrm{Li}$ - and Na-based batteries. Li metal is an attractive anode material for high energy density rechargeable batteries, and extensive efforts have been devoted to developing Li metal batteries (LMBs). However, the practical application of Li metal anode is hindered by the unfavourable dendritic Li growth during repeated charge/discharge processes and the low Coulombic efficiency due to the side reactions of the electrolytes with Li metal. ${ }^{40,43-45,47,48}$ One of the effective approaches to address these issues is to develop the electrolyte that forms a stable and uniform solid-electrolyte interphase (SEI) on the Li metal surface. ${ }^{41,42,46,49,50}$ Aprotic electrolytes reductively decompose on the Li metal, and the decomposition products form an SEI layer on the Li metal electrode. SEI layer is considered to be an electronic insulator but a Li-ion conductor, and SEI can suppress the subsequent decomposition of electrolytes and enables the electrochemical Li metal deposition/dissolution. The stability of SEI layer gives the significant effects on the Coulombic efficiency of $\mathrm{Li}$ deposition/dissolution, and the distribution of SEI on Li metal affects the morphology of the deposited $\mathrm{Li}$ metal. The composition and properties of SEI are strongly affected by the electrolyte formulation such as solvents, anions, and salt concentration. Several research groups reported that highly concentrated LiFSA-based electrolytes are effective in suppressing the dendritic Li metal deposition and the reductive decomposition of the electrolyte at the Li metal electrode, resulting in the highly reversible Li metal deposition/dissolution. For example, Qian et al. reported that a $\mathrm{Li} / \mathrm{Cu}$ cell with $4 \mathrm{~mol} \mathrm{dm}{ }^{-3} \mathrm{LiFSA} / \mathrm{G} 1$ electrolyte can be cycled for more than 1000 cycles without the dendrite growth of Li metal (Fig. 13) and a high average Coulombic efficiency of 98.4\%. ${ }^{52}$ This excellent cycling performance of Li metal electrode can be attributed to the improved electrolyte reductive stability due to reduced availability of reactive solvent and the formation of FSA-derived SEI layer. In the highly concentrated electrolytes, most of the anions form complexes with $\mathrm{Li}^{+}$ions due to the deficiency of solvent (vide supra). According to the computational studies reported by Yamada et al., the complexation of the anion with $\mathrm{Li}^{+}$ ion in the highly concentrated electrolytes leads to the lowering of the lowest unoccupied molecular orbital (LUMO) energy level of anion, and the $\mathrm{FSA}^{-}$anion reductively decomposes prior to the decomposition of the solvent. ${ }^{104,105}$ The decomposition products of the $\mathrm{FSA}^{-}$anion form the effective SEI layer mainly composed of inorganic species such as LiF on the Li metal surface, which may induce uniform Li deposition and effectively suppress the reductive decomposition of the electrolyte. ${ }^{33,53,56,106-108}$

\section{2. $\mathrm{Li}^{+}$intercalation into graphite electrode}

Electrochemical $\mathrm{Li}^{+}$intercalation into graphite has been exploited as a negative electrode reaction in LIBs. Ethylene carbonate (EC) is known to be an essential electrolyte solvent because its reductive decomposition products form an effective passivation film on the graphite surface and suppress the further reductive decomposition of the electrolyte and co-intercalation of solvent into the interlayer of graphite during
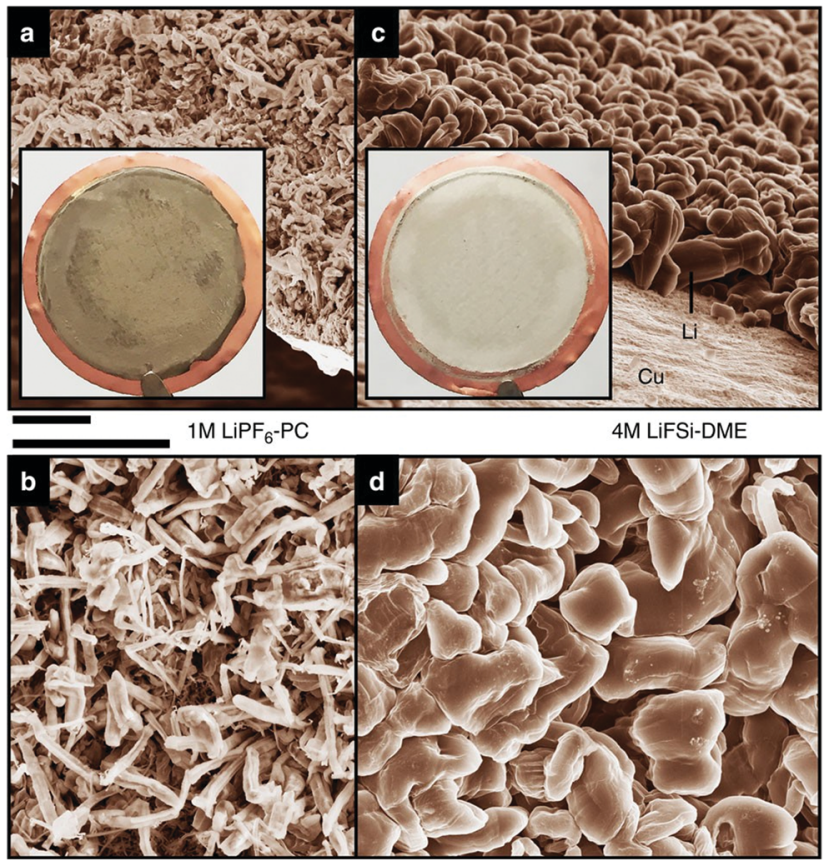

Fig. 13 Scanning electron microscope images of the morphologies of $\mathrm{Li}$ metal after plating on $\mathrm{Cu}$ substrates in different electrolytes. ( $a$ and $b$ ) $1 \mathrm{~mol} \mathrm{dm}^{-3} \mathrm{LiPF}_{6} / \mathrm{PC}$. (c and d) $4 \mathrm{~mol} \mathrm{dm}{ }^{-3}$ LiFSA/DME (G1). The current density was $1.0 \mathrm{~mA} \mathrm{~cm}^{-2}$ and the deposition time was $1.5 \mathrm{~h}$. The diameter of the Cu substrate shown in the inset of (a and c) was $2 \mathrm{~cm}$. Scale bar, $10 \mu \mathrm{m}$. Reprinted with permission from ref. 52 Copyright 2015 Nature Publishing Group.

the $\mathrm{Li}^{+}$intercalation process. ${ }^{109-111}$ However, several groups reported that the co-intercalation of the solvent can be suppressed and reversible $\mathrm{Li}^{+}$intercalation into graphite electrode can occur in highly concentrated electrolytes without EC. ${ }^{4,104,112-115}$ We reported the effect of salt-concentration on the electrochemical reaction of the graphite electrode in LiTFSA/G3 mixtures. ${ }^{58}$ In electrolytes containing excess G3 $(n>1$ in $\left.\left[\mathrm{Li}(\mathrm{G} 3)_{n}\right][\mathrm{TFSA}]\right)$, irreversible co-intercalation of $\mathrm{G} 3$ and $\mathrm{Li}^{+}$, i.e. intercalation of solvated $\mathrm{Li}^{+}\left(\left[\mathrm{Li}(\mathrm{G} 3)_{1}\right]^{+}\right)$, takes place. By contrast, a reversible $\mathrm{Li}^{+}$intercalation reaction (desolvation of $\mathrm{Li}^{+}$) is observed in the molten $\left[\mathrm{Li}(\mathrm{G} 3)_{1}\right][\mathrm{TFSA}]$ complex. The electrode potential of the $\mathrm{Li}^{+}$intercalation reaction changes significantly depending on not only the solvate $\left[\mathrm{Li}(\mathrm{G} 3)_{1}\right]^{+}$cation activity but also the free G3 activity in the electrolyte because of the desolvation of $\mathrm{Li}^{+}$at the interface during $\mathrm{Li}^{+}$intercalation, as well as in the case of $\mathrm{Li}$ metal deposition (eqn (3)). By contrast, the electrode potential for the intercalation of $\left[\mathrm{Li}(\mathrm{G} 3)_{1}\right]^{+}$depends solely on the activity of $\left[\mathrm{Li}(\mathrm{G} 3)_{1}\right]^{+}$, irrespective of the free G3 activity. In the molten [Li(G3) $\left.{ }_{1}\right][$ TFSA] complex, the activity of free G3 is negligible, and the electrode potential of $\mathrm{Li}^{+}$intercalation is anticipated to increase because of the significantly low activity of G3 and the high activity of $\left[\mathrm{Li}(\mathrm{G} 3)_{1}\right]^{+}$. The increase in the chemical potential of $\left[\mathrm{Li}(\mathrm{G} 3)_{1}\right]^{+}$, i.e. destabilisation of solvated $\mathrm{Li}^{+}$, may induce the desolvation of $\mathrm{Li}^{+}$at the interface between the graphite electrode and the molten complex. In addition to the electrode potential shift, the SEI formed on the graphite electrode is also an important factor. Yamada et al. reported that the SEI derived from anions is formed on the graphite 
electrode and kinetically suppresses the solvent co-intercalation in highly concentrated LiTFSA solutions. ${ }^{104,105}$ Thus, both thermodynamic and kinetic effects may contribute to the reversible $\mathrm{Li}^{+}$ intercalation into a graphite electrode in highly concentrated electrolytes.

The anion species in highly concentrated electrolytes significantly influences the kinetics of the $\mathrm{Li}^{+}$interaction reaction of graphite. Fig. 14 exhibits the charging (lithiation) curves of the graphite electrodes measured at various current densities in the SL-based electrolytes. On increasing the current density, the charging capacity of the graphite electrode decreases because the overvoltage for charging increases with the current density, and the voltage of the Li/graphite cell reaches the cut-off voltage $(0 \mathrm{~V})$ prior to achieving the full capacity of the graphite. As shown in Fig. 14, the rate capability of the cell greatly depends on the anionic species in the electrolyte. EIS was performed to investigate the kinetics of the electrochemical reactions in the Li/graphite cells. Fig. 15a shows the Nyquist plots for the cells acquired at a $67 \%$ state of charge (cell voltage $\sim 75 \mathrm{mV}$ ). A depressed semicircle is observed for each cell in the high-frequency region; the diameter of this semicircle is assigned to the interfacial resistance $\left(R_{\text {int }}\right)$ of the electrochemical reactions in a cell. As shown in Fig. 15b, the interfacial resistance of the $\mathrm{Li}$ electrode in each electrolyte is smaller than that of the $\mathrm{Li}$ / graphite cell with each electrolyte. Therefore, the difference in $R_{\text {int }}$ value of the Li/graphite cells with different electrolytes is mainly ascribed to the difference in the resistance of the graphite/electrolyte interface. The $R_{\text {int }}$ value of the Li/graphite cell with $\left[\mathrm{Li}(\mathrm{SL})_{3}\right][\mathrm{FSA}]$ electrolyte is considerably smaller than that of ones with $\left[\mathrm{Li}(\mathrm{SL})_{2}\right]\left[\mathrm{BF}_{4}\right]$ and $\left[\mathrm{Li}(\mathrm{SL})_{2}\right][\mathrm{TFSA}]$ electrolytes, leading to the high rate capability of the cell with $\left[\mathrm{Li}(\mathrm{SL})_{3}\right][\mathrm{FSA}]$ (Fig. 14). The anion species in highly concentrated electrolytes may affect the composition and resistance of the SEI on the graphite electrode. Further investigations may be needed to fully understand the interfacial kinetics of $\mathrm{Li}^{+}$intercalation at the graphite/highly concentrated electrolyte interface.

\subsection{Oxidative stability}

Side reactions on the positive electrode side of LIBs can also be prevented by reducing the solvent activity in the electrolyte. Ethers have not been utilised as electrolyte solvents for $4 \mathrm{~V}$ class lithium batteries because they are oxidised at around $4 \mathrm{~V} v s$. $\mathrm{Li} / \mathrm{Li}^{+} \cdot{ }^{116}$ However, $4 \mathrm{~V}$ class lithium batteries with glyme-LiTFSA molten solvates can be charged and discharged reversibly despite the use of ether-based electrolytes. The oxidative stability is enhanced by decreasing the activity of free glyme. ${ }^{20}$ Furthermore, according to $a b$ initio molecular orbital calculations, the highest occupied molecular orbital (HOMO) energy level of the solvent is lowered by complexation with $\mathrm{Li}^{+}$ions, leading to an enhanced oxidative stability. This should also be true for solvate electrolytes other than glyme solvates. The oxidative stability enhancement of the electrolytes is useful in suppressing the irreversible decomposition of the electrolytes on the positive electrode surface
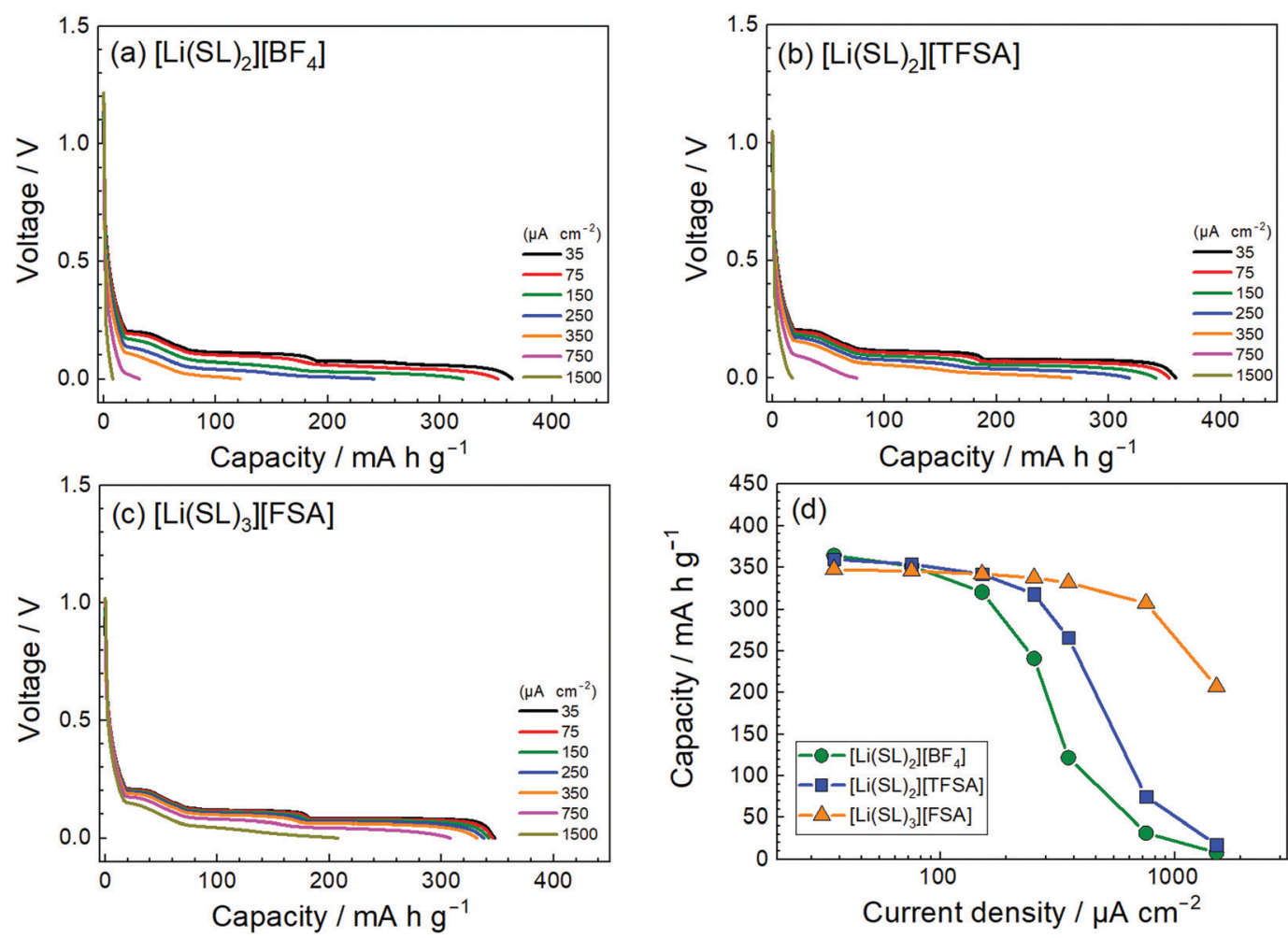

Fig. 14 Charge curves for the Li/graphite cells containing electrolytes of (a) [Li(SL) $\left.)_{2}\right]\left[\mathrm{BF}_{4}\right]$, (b) [Li(SL) $\left.)_{2}\right][T F S A]$, and (c) [Li(SL) $\left.)_{3}\right][F S A]$ at various current densities at $30^{\circ} \mathrm{C}$. (d) Charge capacities of the cells as functions of current density. Following each charge measurement, the cell was fully discharged at the low current density of $35 \mu \mathrm{A} \mathrm{cm}{ }^{-2}$. 

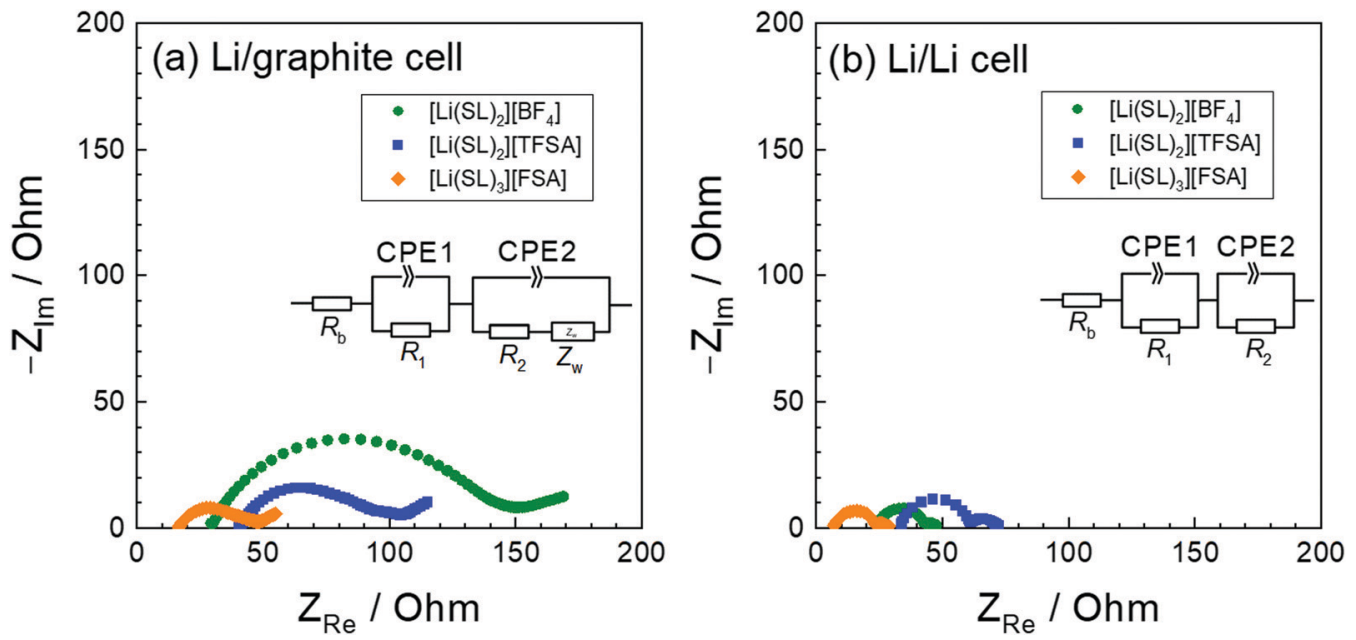

Fig. 15 Nyquist plots of (a) Li/graphite cells at a $67 \%$ state of charge in the 3 rd cycle and (b) Li/Li symmetric cells containing electrolytes of [Li(SL) $\left.{ }_{2}\right]\left[B F_{4}\right]$, $\left[\mathrm{Li}(\mathrm{SL})_{2}\right][\mathrm{TFSA}]$, and $\left[\mathrm{Li}(\mathrm{SL})_{3}\right][\mathrm{FSA}]$ at $30{ }^{\circ} \mathrm{C}$. The geometrical areas of the Li-metal and graphite electrodes were both $2.0 \mathrm{~cm}^{2}$.

in LIBs, and may be instrumental in achieving the highly efficient charge-discharge and the long cycle performance of a high voltage LIB. $^{117}$

\subsection{Suppression of corrosion of Al current collectors}

It is known that the corrosion of $\mathrm{Al}$ current collectors occurs at electrode potentials higher than $4 \mathrm{~V} v s . \mathrm{Li} / \mathrm{Li}^{+}$in the electrolyte containing amide-type anions; ${ }^{118-120}$ therefore, the amidebased Li salts are not utilised as the main electrolyte salts in LIBs. However, Al corrosion can be suppressed by decreasing the solvent activity. ${ }^{77,121-123}$ In LiTFSA-based dilute electrolyte solutions, a large amount of the free solvent easily dissolves the $\mathrm{Al}$-TFSA complexes produced by corrosion at the Al/electrolyte interface, resulting in severe $\mathrm{Al}$ corrosion. ${ }^{124,125}$ By contrast, in highly concentrated electrolytes, the scarcity of the free solvent leads to the extremely low solubility of the Al-TFSA complexes, and they act as a passivation layer on the $\mathrm{Al}$ surface.

\subsection{Oxygen reduction reaction}

The proportion of free solvent molecules in the electrolyte solution influences the oxygen reduction reaction (ORR) in $\mathrm{Li}-\mathrm{O}_{2}$ batteries. The ORR in $\mathrm{Li}-\mathrm{O}_{2}$ batteries utilising nonaqueous electrolyte solutions is known to proceed via one-electron reduction of $\mathrm{O}_{2}$ to produce soluble lithium superoxide $\left(\mathrm{LiO}_{2}\right)$. Subsequently, $\mathrm{LiO}_{2}$ is electrochemically reduced and/or the chemical disproportionation reaction of $\mathrm{LiO}_{2}$ proceeds to produce solid lithium peroxide $\left(\mathrm{Li}_{2} \mathrm{O}_{2}\right)$, as follows: ${ }^{126,127}$

$$
\begin{gathered}
\mathrm{O}_{2}+\mathrm{Li}^{+}+\mathrm{e}^{-} \rightarrow \mathrm{LiO}_{2} \\
\mathrm{LiO}_{2}+\mathrm{Li}^{+}+\mathrm{e}^{-} \rightarrow \mathrm{Li}_{2} \mathrm{O}_{2} \\
2 \mathrm{LiO}_{2} \rightarrow \mathrm{Li}_{2} \mathrm{O}_{2}+\mathrm{O}_{2}
\end{gathered}
$$

The parasitic reactions of the highly reactive $\mathrm{LiO}_{2}$ with the electrolyte components and/or carbon electrode hinder the long-term operation of $\mathrm{Li}-\mathrm{O}_{2}$ batteries. ${ }^{128-131}$ In our previous study, we investigated the effects of the Li salt concentration on the reversibility of the ORR in LiTFSA/dimethyl sulfoxide (DMSO) solutions. ${ }^{38}$ The ORR in 1 and $3 \mathrm{~mol} \mathrm{dm}^{-3}$ LiTFSA/ DMSO solutions was assessed by rotating ring-disk electrode (RRDE) measurements (Fig. 16). In each electrolyte, the current for the ORR was observed during the cathodic scan of the disk electrode, and the current for the oxygen evolution reaction (OER) appeared during the anodic scan. The reversibility of OER/ORR is improved by increasing the LiTFSA concentration in the electrolyte. The Coulombic efficiencies for OER/ORR at the disk electrode are $32 \%$ and $58 \%$ in the 1 and $3 \mathrm{~mol} \mathrm{dm}^{-3}$ LiTFSA/DMSO solutions, respectively. The difference in the Coulombic efficiencies was mainly due to the difference in the $\mathrm{LiO}_{2}$ solubility in the solution. In the $1 \mathrm{~mol} \mathrm{dm}^{-3}$ solution, the anodic current was detected at the ring electrode, where the potential of the ring electrode was set at $3.3 \mathrm{~V} v \mathrm{v}$. Li, indicating that the $\mathrm{LiO}_{2}$ (generated at the disk electrode) partially dissolved into the solution and was oxidised at the ring electrode. By contrast, the ring current was negligible for the $3 \mathrm{~mol} \mathrm{dm}{ }^{-3}$ solution, suggesting that $\mathrm{LiO}_{2}$ hardly dissolves in the highly concentrated solution. Raman spectroscopy revealed that the fraction of DMSO bound to $\mathrm{Li}^{+}$and free DMSO increases and decreases, respectively, with increasing LiTFSA concentration as shown in Fig. $17 .{ }^{38}$ Free DMSO was found to be $8.7 \%$ in the $2.3 \mathrm{~mol} \mathrm{dm}^{-3}$ solution (Li[TFSA]: DMSO = 1:4), and only trace amounts of free DMSO were present in the high concentration LiTFSA/DMSO solutions above $2.3 \mathrm{~mol} \mathrm{dm}^{-3}$. It is considered that $\mathrm{LiO}_{2}$ cannot be solvated in a highly concentrated electrolyte because of the absence of free solvent, resulting in very low solubility of $\mathrm{LiO}_{2}$. Therefore, $\mathrm{LiO}_{2}$ is converted to $\mathrm{Li}_{2} \mathrm{O}_{2}$ mainly on the disk electrode surface, resulting in an improved reversibility of the OER/ORR at the disk electrode.

\subsection{Li-S batteries}

Elimination of the free solvent in the electrolyte solution is an effective strategy for highly reversible lithium-sulphur ( $\mathrm{Li}-\mathrm{S}$ ) batteries. Li-S batteries have attracted considerable attention 

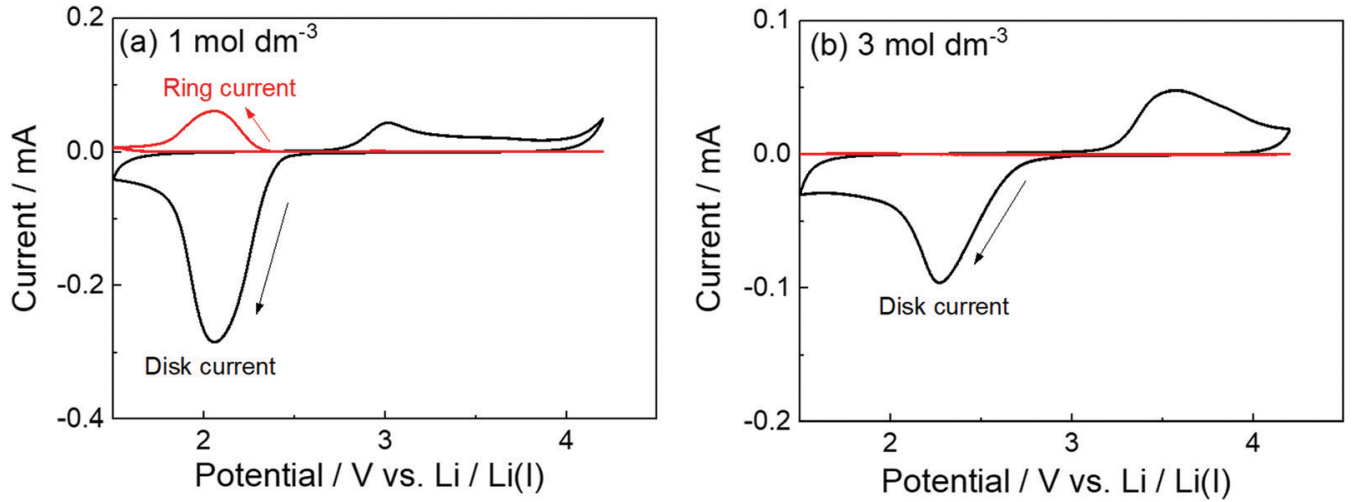

Fig. 16 RRDE responses on glassy carbon (GC) disk/GC ring electrode measured at $1000 \mathrm{rpm}$ at $100 \mathrm{mV} \mathrm{s}^{-1}$ in $\mathrm{O}_{2}$ saturated (a) $1 \mathrm{~mol} \mathrm{dm}^{-3}$ and (b) $3 \mathrm{~mol} \mathrm{dm}{ }^{-3}$ LiTFSA/DMSO at $30{ }^{\circ} \mathrm{C}$. Reference electrode: Li metal in $1 \mathrm{~mol} \mathrm{dm}{ }^{-3}$ LiTFSA/G3. The potential of the GC disk electrode was swept from the open circuit potential (OCP) of ca. $3 \mathrm{~V}$ vs. Li/Li to the negative direction, and the sweep direction was reversed at $1.5 \mathrm{~V} v \mathrm{~s}$. Li/Li ${ }^{+}$. The potential of the GC ring electrode was set at $3.3 \mathrm{~V}$ vs. Li/Li ${ }^{+}$. Reprinted and partially modified with permission from ref. 38. Copyright 2017 American Chemical Society.

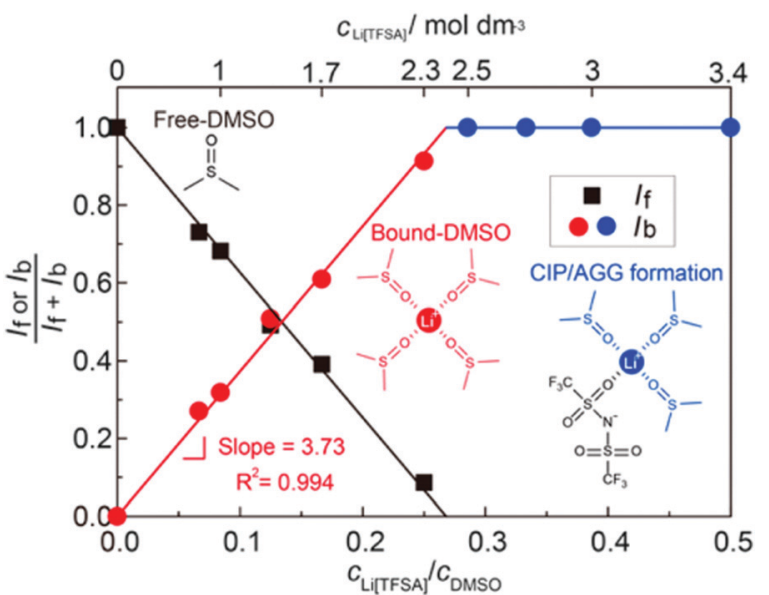

Fig. 17 Fraction of the integrated intensities of Raman peaks corresponding to free DMSO, $I_{f} /\left(I_{f}+I_{b}\right)$ and bound DMSO, $I_{b} /\left(I_{f}+I_{b}\right)$ in the Li[TFSA]/DMSO solutions. Reprinted with permission from ref. 38 Copyright 2017 American Chemical Society.

for their high theoretical energy density because of the high theoretical capacities of the $\mathrm{S}$ cathode $\left(1672 \mathrm{~mA} \mathrm{~h} \mathrm{~g}^{-1}\right)$ and $\mathrm{Li}$ metal anode (3860 $\mathrm{mA} \mathrm{h} \mathrm{g}^{-1}$ ) compared with the typical electrodes used in conventional LIBs such as $\mathrm{LiNi}_{1 / 3} \mathrm{Mn}_{1 / 3} \mathrm{Co}_{1 / 3} \mathrm{O}_{2}$ cathode $\left(160 \mathrm{~mA} \mathrm{~h} \mathrm{~g}^{-1}\right)$ and graphite anode $\left(372 \mathrm{~mA} \mathrm{~h} \mathrm{~g}^{-1}\right) .{ }^{126,132}$ One of the obstacles hindering the practical use of $\mathrm{Li}-\mathrm{S}$ batteries is the dissolution of lithium polysulfides (LPS), which are the reaction intermediates of the $\mathrm{S}$ cathode. The dissolution of LPS causes a low Coulombic efficiency of discharge/charge and a loss of the active materials from the positive electrode. ${ }^{133-135}$ To solve these issues, for the first time, we proposed the glyme-Li salt molten complexes as sparingly solvating electrolytes for $\mathrm{Li}-\mathrm{S}$ batteries. ${ }^{22}$ The solubility of LPS in molten complex electrolytes is very low, owing to the lack of free solvent molecules having high solute solvating abilities. Thus, the Li-S cells can be charged and discharged for more than 400 cycles with high Coulombic efficiencies of over $98 \%$. (a)

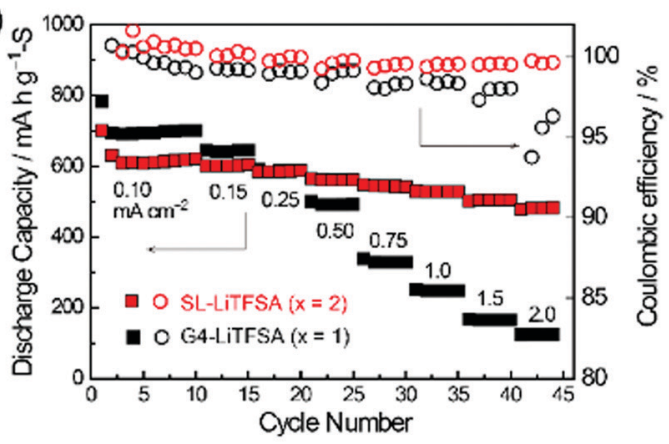

(b)

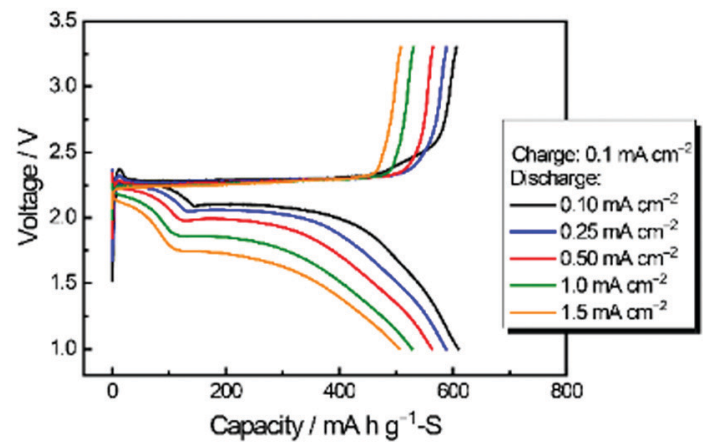

(c)

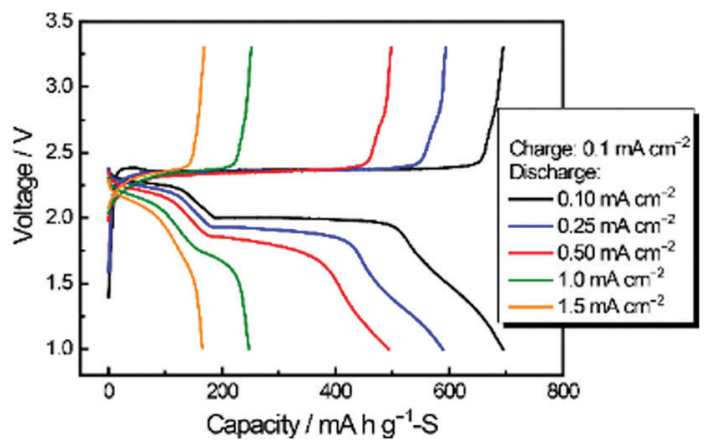

Fig. 18 (a) Discharge capacity and Coulombic efficiency at different discharge current densities, and charge and discharge curves of the cells using the concentrated electrolytes, (b) [Li(SL) 2 ] $T$ TFSA] and (c) $\left[\mathrm{Li}(\mathrm{G} 4)_{1}\right][\mathrm{TFSA}$. Reprinted with permission from ref. 39 Copyright 2019 American Chemical Society. 
Highly concentrated SL-based electrolytes also function as sparingly solvating electrolytes in Li-S cells. SL-based electrolytes possessing high $\mathrm{Li}^{+}$ion transference number via $\mathrm{Li}^{+}$ion hopping conduction enabled a higher rate performance of the Li-S cell. ${ }^{39}$ Fig. 18 exhibits the charge and discharge performances of $\mathrm{Li}-\mathrm{S}$ cells with molten solvate electrolytes $\left[\mathrm{Li}(\mathrm{SL})_{2}\right][\mathrm{TFSA}]$ and $\left[\mathrm{Li}(\mathrm{G} 4)_{1}\right][\mathrm{TFSA}]$. Both cells show high Coulombic efficiencies ( $>98 \%$ ) owing to the limited solubility of LPS in the electrolytes. Interestingly, the cell with the SL-based solvate exhibited a higher rate capability than one with the G4-based solvate, regardless of the lower ionic conductivity of the former electrolyte (SL: $0.42 \mathrm{mS} \mathrm{cm}{ }^{-1} v s$. G4: $1.6 \mathrm{mS} \mathrm{cm}^{-1}$ ). The difference in the rate capability can be attributed to the difference in the $\mathrm{Li}^{+}$transference number $\left(t_{\mathrm{Li}}^{\mathrm{PP}}\right)$ of the electrolytes. The $t_{\mathrm{Li}}^{\mathrm{PP}}$ of the SL-based molten solvate is 0.68 , which is much higher than that of the glyme-based solvate $\left(t_{\mathrm{Li}}^{\mathrm{PP}}=0.028\right) .{ }^{87}$ The higher $t_{\mathrm{Li}}^{\mathrm{PP}}$ decelerates the growth of the Li salt concentration gradient in the vicinity of the sulphur cathode during the high-rate discharge, which mitigates the concentration polarisation, leading to a higher rate of capability of the cell.

\section{Summary and outlook}

In this article, the structures, physicochemical properties, and transport properties of molten solvate electrolytes were reviewed. In molten solvate, the activity of the free solvent is negligible. This is one of the main causes for the peculiar features of molten solvates, such as high thermal stability, wide electrochemical window, and unique ion transport. The liquid structures of the molten solvates significantly affect the transport properties. In molten solvates, the solvated cations and anions are adjacent to each other, resulting in hopping/ligand exchange conduction of alkali metal ions in certain molten solvate electrolytes. The $\mathrm{Li}$ ion hopping/ligand exchange conduction increases the transference number of Li ions in the electrolyte, and this is effective in enhancing the rate capability of lithium batteries. The solvent activity influences the electrochemical reaction processes in the electrolyte. The electrode potential changes significantly depending on the solvent activity. The solubility of the electrochemically generated products decreases with decreasing solvent activity in the electrolyte. This is effective in suppressing the corrosion of the Al current collector, achieving the high reversibility of the ORR/OER, and increasing the Coulombic efficiency of charge/discharge of a $\mathrm{Li}-\mathrm{S}$ cell. In solvent-deficient $\mathrm{Li}$ salt solutions, the complex formation of $\mathrm{Li}^{+}$ and anions is induced, which affects the formation of SEI layers on Li metal and graphite electrodes. Electrochemistry in the molten solvates of $\mathrm{Na}$ salts are also significantly influenced by the solvent activity and anion species. ${ }^{34,35,136,137}$ The concept of solvate electrolytes can be expanded further; for example, the molten solvates of $\mathrm{K}, \mathrm{Mg}$, $\mathrm{Ca}$, and $\mathrm{Zn}$ salts may be preparable and useful as battery electrolytes.

The drawbacks of molten solvate electrolytes are their high viscosity and relatively low ionic conductivity compared with that of the conventional electrolytes. The strong interactions of the cation with the solvent and anion cause the high viscosity and low mobility of the ions. The low viscosity and highly conductive molten solvates are favourable for use as battery electrolytes. To achieve this, the selection and design of solvents and anions are crucial. In addition, understanding the dynamics of ion conduction and interfacial charge transfer reactions is important for the development of new solvate electrolytes. For instance, the rotational motions and conformational changes of the solvent and anions may affect the ion conduction and electrochemical reaction mechanisms in the molten solvate electrolytes. Further experimental and computational studies on the dynamics are required to provide useful insights.

\section{Conflicts of interest}

There are no conflicts to declare.

\section{Acknowledgements}

This study was partially supported by JSPS KAKENHI (Grant No. 18H03926, 19H05813, 20J20165, and 21H04697) from the Japan Society for the Promotion of Science (JSPS), ALCA-SPRING (Grant No. JPMJAL1301) from the Japan Science and Technology Agency (JST), and the Element Strategy Initiative of MEXT (Grant No. JPMXP0112101003) from the Ministry of Education, Culture, Sports, Science, and Technology, Japan. The authors thank Mr. Shohei Sasagawa (Yokohama National University) for performing the electrochemical measurements of the graphite electrodes.

\section{References}

1 K. Xu, Chem. Rev., 2004, 104, 4303-4418.

2 D. Brouillette, G. Perron and J. E. Desnoyers, J. Solution Chem., 1998, 27, 151-182.

3 K. Izutsu, Electrochemistry in Nonaqueous Solutions, WileyVCH Verlag GmbH \& Co. KGaA, Weinheim, 2nd edn, 2009.

4 S.-K. Jeong, M. Inaba, Y. Iriyama, T. Abe and Z. Ogumi, J. Power Sources, 2008, 175, 540-546.

5 Y. Yamada and A. Yamada, J. Electrochem. Soc., 2015, 162, A2406-A2423.

6 M. Watanabe, M. L. Thomas, S. Zhang, K. Ueno, T. Yasuda and K. Dokko, Chem. Rev., 2017, 117, 7190-7239.

7 Y. Yamada, J. Wang, S. Ko, E. Watanabe and A. Yamada, Nat. Energy, 2019, 4, 269-280.

8 O. Borodin, J. Self, K. A. Persson, C. Wang and K. Xu, Joule, 2020, 4, 69-100.

9 M. Li, C. Wang, Z. Chen, K. Xu and J. Lu, Chem. Rev., 2020, 120, 6783-6819.

10 S.-A. Hyodo and K. Okabayashi, Electrochim. Acta, 1989, 34, 1551-1556.

11 M. Morita, Y. Asai, N. Yoshimoto and M. Ishikawa, J. Chem. Soc., Faraday Trans., 1998, 94, 3451-3456. 
12 Y. Kameda, Y. Umebayashi, M. Takeuchi, M. A. Wahab, S. Fukuda, S. Ishiguro, M. Sasaki, Y. Amo and T. Usuki, J. Phys. Chem. B, 2007, 111, 6104-6109.

13 D. Monti, E. Jónsson, M. R. Palacín and P. Johansson, J. Power Sources, 2014, 245, 630-636.

14 R. Tatara, G. M. Leverick, S. Feng, S. Wan, S. Terada, K. Dokko, M. Watanabe and Y. Shao-Horn, J. Phys. Chem. C, 2018, 122, 18316-18328.

15 J. Grondin, D. Talaga, J.-C. Lassègues and W. A. Henderson, Phys. Chem. Chem. Phys., 2004, 6, 938-944.

16 J. Grondin, J.-C. Lassègues, M. Chami, L. Servant, D. Talaga and W. A. Henderson, Phys. Chem. Chem. Phys., 2004, 6, 4260-4267.

17 W. A. Henderson, F. McKenna, M. A. Khan, N. R. Brooks, V. G. Young and R. Frech, Chem. Mater., 2005, 17, 2284-2289. 18 W. A. Henderson, J. Phys. Chem. B, 2006, 110, 13177-13183. 19 T. Tamura, K. Yoshida, T. Hachida, M. Tsuchiya, M. Nakamura, Y. Kazue, N. Tachikawa, K. Dokko and M. Watanabe, Chem. Lett., 2010, 39, 753-755.

20 K. Yoshida, M. Nakamura, Y. Kazue, N. Tachikawa, S. Tsuzuki, S. Seki, K. Dokko and M. Watanabe, J. Am. Chem. Soc., 2011, 133, 13121-13129.

21 K. Yoshida, M. Tsuchiya, N. Tachikawa, K. Dokko and M. Watanabe, J. Phys. Chem. C, 2011, 115, 18384-18394.

22 K. Dokko, N. Tachikawa, K. Yamauchi, M. Tsuchiya, A. Yamazaki, E. Takashima, J.-W. Park, K. Ueno, S. Seki, N. Serizawa and M. Watanabe, J. Electrochem. Soc., 2013, 160, A1304-A1310.

23 H. Moon, T. Mandai, R. Tatara, K. Ueno, A. Yamazaki, K. Yoshida, S. Seki, K. Dokko and M. Watanabe, J. Phys. Chem. C, 2015, 119, 3957-3970.

24 K. Ueno, K. Yoshida, M. Tsuchiya, N. Tachikawa, K. Dokko and M. Watanabe, J. Phys. Chem. B, 2012, 116, 11323-11331.

25 T. Mandai, K. Dokko and M. Watanabe, Chem. Rec., 2019, 19, 708-722.

26 T. Mandai, K. Yoshida, K. Ueno, K. Dokko and M. Watanabe, Phys. Chem. Chem. Phys., 2014, 16, 8761-8772.

27 M. Watanabe, K. Dokko, K. Ueno and M. L. Thomas, Bull. Chem. Soc. Jpn., 2018, 91, 1660-1682.

28 L. Suo, O. Borodin, T. Gao, M. Olguin, J. Ho, X. Fan, C. Luo, C. Wang and K. Xu, Science, 2015, 350, 938-943.

29 L. Suo, O. Borodin, W. Sun, X. Fan, C. Yang, F. Wang, T. Gao, Z. Ma, M. Schroeder, A. von Cresce, S. M. Russell, M. Armand, A. Angell, K. Xu and C. Wang, Angew. Chem., Int. Ed., 2016, 55, 7136-7141.

30 Y. Yamada, K. Usui, K. Sodeyama, S. Ko, Y. Tateyama and A. Yamada, Nat. Energy, 2016, 1, 16129.

31 K. Dokko, D. Watanabe, Y. Ugata, M. L. Thomas, S. Tsuzuki, W. Shinoda, K. Hashimoto, K. Ueno, Y. Umebayashi and M. Watanabe, J. Phys. Chem. B, 2018, 122, 10736-10745.

32 J. Alvarado, M. A. Schroeder, M. Zhang, O. Borodin, E. Gobrogge, M. Olguin, M. S. Ding, M. Gobet, S. Greenbaum, Y. S. Meng and K. Xu, Mater. Today, 2018, 21, 341-353.
33 X. Ren, S. Chen, H. Lee, D. Mei, M. H. Engelhard, S. D. Burton, W. Zhao, J. Zheng, Q. Li, M. S. Ding, M. Schroeder, J. Alvarado, K. Xu, Y. S. Meng, J. Liu, J. G. Zhang and W. Xu, Chem, 2018, 4, 1877-1892.

34 Y. Okamoto, S. Tsuzuki, R. Tatara, K. Ueno, K. Dokko and M. Watanabe, J. Phys. Chem. C, 2020, 124, 4459-4469.

35 R. Tatara, S. Nishimura, Y. Okamoto, K. Ueno, M. Watanabe and K. Dokko, J. Phys. Chem. C, 2020, 124, 15800-15811.

36 J. Wang, Y. Yamada, K. Sodeyama, C. H. Chiang, Y. Tateyama and A. Yamada, Nat. Commun., 2016, 7, 12032. 37 S. Ko, Y. Yamada and A. Yamada, Joule, 2021, 5, 998-1009. 38 R. Tatara, D. G. Kwabi, T. P. Batcho, M. Tulodziecki, K. Watanabe, H. M. Kwon, M. L. Thomas, K. Ueno, C. V. Thompson, K. Dokko, Y. Shao-Horn and M. Watanabe, J. Phys. Chem. C, 2017, 121, 9162-9172.

39 A. Nakanishi, K. Ueno, D. Watanabe, Y. Ugata, Y. Matsumae, J. Liu, M. L. Thomas, K. Dokko and M. Watanabe, J. Phys. Chem. C, 2019, 123, 14229-14238.

40 W. Xu, J. Wang, F. Ding, X. Chen, E. Nasybulin, Y. Zhang and J.-G. Zhang, Energy Environ. Sci., 2014, 7, 513-537.

41 X. B. Cheng, R. Zhang, C. Z. Zhao, F. Wei, J. G. Zhang and Q. Zhang, Adv. Sci., 2016, 3, 1500213.

42 M. D. Tikekar, S. Choudhury, Z. Tu and L. A. Archer, Nat. Energy, 2016, 1, 16114.

43 D. Lin, Y. Liu and Y. Cui, Nat. Nanotechnol., 2017, 12, 194-206.

44 X. B. Cheng, R. Zhang, C. Z. Zhao and Q. Zhang, Chem. Rev., 2017, 117, 10403-10473.

45 J. Liu, Z. Bao, Y. Cui, E. J. Dufek, J. B. Goodenough, P. Khalifah, Q. Li, B. Y. Liaw, P. Liu, A. Manthiram, Y. S. Meng, V. R. Subramanian, M. F. Toney, V. V. Viswanathan, M. S. Whittingham, J. Xiao, W. Xu, J. Yang, X.-Q. Yang and J.-G. Zhang, Nat. Energy, 2019, 4, 180-186.

46 R. Weber, M. Genovese, A. J. Louli, S. Hames, C. Martin, I. G. Hill and J. R. Dahn, Nat. Energy, 2019, 4, 683-689.

47 C. Fang, X. Wang and Y. S. Meng, Trends Chem., 2019, 1, 152-158.

48 Y. Zhang, T.-T. Zuo, J. Popovic, K. Lim, Y.-X. Yin, J. Maier and Y.-G. Guo, Mater. Today, 2020, 33, 56-74.

49 J. G. Zhang, W. Xu, J. Xiao, X. Cao and J. Liu, Chem. Rev., 2020, 120, 13312-13348.

50 Z. Yu, H. Wang, X. Kong, W. Huang, Y. Tsao, D. G. Mackanic, K. Wang, X. Wang, W. Huang, S. Choudhury, Y. Zheng, C. V. Amanchukwu, S. T. Hung, Y. Ma, E. G. Lomeli, J. Qin, Y. Cui and Z. Bao, Nat. Energy, 2020, 5, 526-533.

51 L. Suo, Y. S. Hu, H. Li, M. Armand and L. Chen, Nat. Commun., 2013, 4, 1481.

52 J. Qian, W. A. Henderson, W. Xu, P. Bhattacharya, M. Engelhard, O. Borodin and J. G. Zhang, Nat. Commun., 2015, 6, 6362.

53 X. Fan, L. Chen, X. Ji, T. Deng, S. Hou, J. Chen, J. Zheng, F. Wang, J. Jiang, K. Xu and C. Wang, Chem, 2017, 4, 174-185. 
54 Z. Zeng, V. Murugesan, K. S. Han, X. Jiang, Y. Cao, L. Xiao, X. Ai, H. Yang, J.-G. Zhang, M. L. Sushko and J. Liu, Nat. Energy, 2018, 3, 674-681.

55 S. Jiao, X. Ren, R. Cao, M. H. Engelhard, Y. Liu, D. Hu, D. Mei, J. Zheng, W. Zhao, Q. Li, N. Liu, B. D. Adams, C. Ma, J. Liu, J.-G. Zhang and W. Xu, Nat. Energy, 2018, 3, 739-746.

56 Y. Maeyoshi, D. Ding, M. Kubota, H. Ueda, K. Abe, K. Kanamura and H. Abe, ACS Appl. Mater. Interfaces, 2019, 11, 25833-25843.

57 J. O. M. Bockris and A. K. N. Reddy, Modern Electrochemistry, Springer, US, New York, 2nd edn, 1998.

58 H. Moon, R. Tatara, T. Mandai, K. Ueno, K. Yoshida, N. Tachikawa, T. Yasuda, K. Dokko and M. Watanabe, J. Phys. Chem. C, 2014, 118, 20246-20256.

59 K. Ueno, R. Tatara, S. Tsuzuki, S. Saito, H. Doi, K. Yoshida, T. Mandai, M. Matsugami, Y. Umebayashi, K. Dokko and M. Watanabe, Phys. Chem. Chem. Phys., 2015, 17, 8248-8257.

60 N. Arai, H. Watanabe, E. Nozaki, S. Seki, S. Tsuzuki, K. Ueno, K. Dokko, M. Watanabe, Y. Kameda and Y. Umebayashi, J. Phys. Chem. Lett., 2020, 11, 4517-4523.

61 C. Zhang, K. Ueno, A. Yamazaki, K. Yoshida, H. Moon, T. Mandai, Y. Umebayashi, K. Dokko and M. Watanabe, J. Phys. Chem. B, 2014, 118, 5144-5153.

62 V. Gutmann and E. Wychera, Inorg. Nucl. Chem. Lett., 1966, 2, 257-260.

63 U. Mayer, V. Gutmann and W. Gerger, Monatsh. Chem., 1975, 106, 1235-1257.

64 K. Ueno, J.-W. Park, A. Yamazaki, T. Mandai, N. Tachikawa, K. Dokko and M. Watanabe, J. Phys. Chem. C, 2013, 117, 20509-20516.

65 G. Leverick, R. Tatara, S. Feng, E. Crabb, A. France-Lanord, M. Tułodziecki, J. Lopez, R. M. Stephens, J. C. Grossman and Y. Shao-Horn, J. Phys. Chem. C, 2020, 124, 4953-4967.

66 T. Mandai, K. Yoshida, S. Tsuzuki, R. Nozawa, H. Masu, K. Ueno, K. Dokko and M. Watanabe, J. Phys. Chem. B, 2015, 119, 1523-1534.

67 S. Terada, T. Mandai, R. Nozawa, K. Yoshida, K. Ueno, S. Tsuzuki, K. Dokko and M. Watanabe, Phys. Chem. Chem. Phys., 2014, 16, 11737-11746.

68 S.-D. Han, J. L. Allen, E. Jónsson, P. Johansson, D. W. McOwen, P. D. Boyle and W. A. Henderson, J. Phys. Chem. C, 2013, 117, 5521-5531.

69 D. M. Seo, P. D. Boyle, R. D. Sommer, J. S. Daubert, O. Borodin and W. A. Henderson, J. Phys. Chem. B, 2014, 118, 13601-13608.

70 D. M. Seo, P. D. Boyle, J. L. Allen, S.-D. Han, E. Jónsson, P. Johansson and W. A. Henderson, J. Phys. Chem. C, 2014, 118, 18377-18386.

71 Y. Ugata, S. Sasagawa, R. Tatara, K. Ueno, M. Watanabe and K. Dokko, J. Phys. Chem. B, 2021, 125, 6600-6608.

72 S. Kondou, M. L. Thomas, T. Mandai, K. Ueno, K. Dokko and M. Watanabe, Phys. Chem. Chem. Phys., 2019, 21, 5097-5105.

73 Y. Ugata, M. L. Thomas, T. Mandai, K. Ueno, K. Dokko and M. Watanabe, Phys. Chem. Chem. Phys., 2019, 21, 9759-9768.
74 J. E. Katon and W. R. Feairheller, Spectrochim. Acta, 1965, 21, 199-201.

75 D. Brouillette, D. E. Irish, N. J. Taylor, G. Perron, M. Odziemkowski and J. E. Desnoyers, Phys. Chem. Chem. Phys., 2002, 4, 6063-6071.

76 Y. Umebayashi, T. Mitsugi, S. Fukuda, T. Fujimori, K. Fujii, R. Kanzaki, M. Takeuchi and S. Ishiguro, J. Phys. Chem. B, 2007, 111, 13028-13032.

77 D. W. McOwen, D. M. Seo, O. Borodin, J. Vatamanu, P. D. Boyle and W. A. Henderson, Energy Environ. Sci., 2014, 7, 416-426.

78 D. M. Seo, O. Borodin, S.-D. Han, P. D. Boyle and W. A. Henderson, J. Electrochem. Soc., 2012, 159, A1489-A1500.

79 Y. Ugata, R. Tatara, K. Ueno, K. Dokko and M. Watanabe, J. Chem. Phys., 2020, 152, 104502.

80 D. M. Seo, O. Borodin, S.-D. Han, Q. Ly, P. D. Boyle and W. A. Henderson, J. Electrochem. Soc., 2012, 159, A553-A565.

81 S.-D. Han, O. Borodin, J. L. Allen, D. M. Seo, D. W. McOwen, S.-H. Yun and W. A. Henderson, J. Electrochem. Soc., 2013, 160, A2100-A2110.

82 S.-D. Han, O. Borodin, D. M. Seo, Z.-B. Zhou and W. A. Henderson, J. Electrochem. Soc., 2014, 161, A2042-A2053.

83 J. Wang, Y. Yamada, K. Sodeyama, E. Watanabe, K. Takada, Y. Tateyama and A. Yamada, Nat. Energy, 2018, 3, 22-29.

84 N. Xiao, W. D. McCulloch and Y. Wu, J. Am. Chem. Soc., 2017, 139, 9475-9478.

85 F. Wohde, M. Balabajew and B. Roling, J. Electrochem. Soc., 2016, 163, A714-A721.

86 P. Porion, Y. R. Dougassa, C. Tessier, L. El Ouatani, J. Jacquemin and M. Anouti, Electrochim. Acta, 2013, 114, 95-104.

87 K. Shigenobu, K. Dokko, M. Watanabe and K. Ueno, Phys. Chem. Chem. Phys., 2020, 22, 15214-15221.

88 K. Hayamizu, Y. Aihara, S. Arai and C. G. Martinez, J. Phys. Chem. B, 1999, 103, 519-524.

89 S. Tsuzuki, W. Shinoda, S. Seki, Y. Umebayashi, K. Yoshida, K. Dokko and M. Watanabe, ChemPhysChem, 2013, 14, 1993-2001.

90 M. Doyle, T. F. Fuller and J. Newman, Electrochim. Acta, 1994, 39, 2073-2081.

91 K. M. Diederichsen, E. J. McShane and B. D. McCloskey, ACS Energy Lett., 2017, 2, 2563-2575.

92 P. Barai, K. Higa and V. Srinivasan, J. Electrochem. Soc., 2018, 165, A2654-A2666.

93 M. Gouverneur, J. Kopp, L. van Wüllen and M. Schönhoff, Phys. Chem. Chem. Phys., 2015, 17, 30680-30686.

94 P. G. Bruce, M. T. Hardgrave and C. A. Vincent, Solid State Ionics, 1992, 53-56, 1087-1094.

95 P. G. Bruce, J. Evans and C. A. Vincent, Solid State Ionics, 1988, 28-30, 918-922.

96 M. Watanabe, S. Nagano, K. Sanui and N. Ogata, Solid State Ionics, 1988, 28-30, 911-917.

97 M. D. Galluzzo, J. A. Maslyn, D. B. Shah and N. P. Balsara, J. Chem. Phys., 2019, 151, 020901. 
98 K. Shigenobu, M. Shibata, K. Dokko, M. Watanabe, K. Fujii and K. Ueno, Phys. Chem. Chem. Phys., 2021, 23, 2622-2629.

99 L. A. Woolf, J. Phys. Chem., 1978, 82, 959-962.

100 L. A. Woolf and K. R. Harris, J. Chem. Soc., Faraday Trans. 1, 1978, 74, 933-947.

101 D. M. Pesko, K. Timachova, R. Bhattacharya, M. C. Smith, I. Villaluenga, J. Newman and N. P. Balsara, J. Electrochem. Soc., 2017, 164, E3569-E3575.

102 I. Villaluenga, D. M. Pesko, K. Timachova, Z. Feng, J. Newman, V. Srinivasan and N. P. Balsara, J. Electrochem. Soc., 2018, 165, A2766-A2773.

103 D. Dong, F. Sälzer, B. Roling and D. Bedrov, Phys. Chem. Chem. Phys., 2018, 20, 29174-29183.

104 Y. Yamada, K. Furukawa, K. Sodeyama, K. Kikuchi, M. Yaegashi, Y. Tateyama and A. Yamada, J. Am. Chem. Soc., 2014, 136, 5039-5046.

105 K. Sodeyama, Y. Yamada, K. Aikawa, A. Yamada and Y. Tateyama, J. Phys. Chem. C, 2014, 118, 14091-14097.

106 L. E. Camacho-Forero, T. W. Smith and P. B. Balbuena, J. Phys. Chem. C, 2016, 121, 182-194.

107 K. Takada, Y. Yamada and A. Yamada, ACS Appl. Mater. Interfaces, 2019, 11, 35770-35776.

108 Y. Ugata, R. Tatara, T. Mandai, K. Ueno, M. Watanabe and K. Dokko, ACS Appl. Energy Mater., 2021, 4, 1851-1859.

109 R. Fong, U. von Sacken and J. R. Dahn, J. Electrochem. Soc., 1990, 137, 2009-2013.

110 D. Aurbach, A. Zaban, Y. Ein-Eli, I. Weissman, O. Chusid, B. Markovsky, M. Levi, E. Levi, A. Schechter and E. Granot, J. Power Sources, 1997, 68, 91-98.

111 D. Aurbach, J. Power Sources, 2000, 89, 206-218.

112 S.-K. Jeong, M. Inaba, Y. Iriyama, T. Abe and Z. Ogumi, Electrochem. Solid-State Lett., 2003, 6, A13-A15.

113 M. Nie, D. P. Abraham, D. M. Seo, Y. Chen, A. Bose and B. L. Lucht, J. Phys. Chem. C, 2013, 117, 25381-25389.

114 Y. Yamada, M. Yaegashi, T. Abe and A. Yamada, Chem. Commun., 2013, 49, 11194-11196.

115 Y. Yamada, K. Usui, C. H. Chiang, K. Kikuchi, K. Furukawa and A. Yamada, ACS Appl. Mater. Interfaces, 2014, 6, 10892-10899.

116 S. Seki, Y. Kobayashi, H. Miyashiro, A. Yamanaka, Y. Mita and T. Iwahori, J. Power Sources, 2005, 146, 741-744.

117 J. Ling, C. Karuppiah, S. G. Krishnan, M. V. Reddy, I. I. Misnon, M. H. Ab Rahim, C.-C. Yang and R. Jose, Energy Fuels, 2021, 35, 10428-10450.

118 L. J. Krause, W. Lamanna, J. Summerfield, M. Engle, G. Korba, R. Loch and R. Atanasoski, J. Power Sources, 1997, 68, 320-325.
119 M. Morita, T. Shibata, N. Yoshimoto and M. Ishikawa, J. Power Sources, 2003, 119-121, 784-788.

120 A. Abouimrane, J. Ding and I. J. Davidson, J. Power Sources, 2009, 189, 693-696.

121 K. Matsumoto, K. Inoue, K. Nakahara, R. Yuge, T. Noguchi and K. Utsugi, J. Power Sources, 2013, 231, 234-238.

122 C. Zhang, A. Yamazaki, J. Murai, J. W. Park, T. Mandai, K. Ueno, K. Dokko and M. Watanabe, J. Phys. Chem. C, 2014, 118, 17362-17373.

123 Y. Yamada, C. H. Chiang, K. Sodeyama, J. Wang, Y. Tateyama and A. Yamada, ChemElectroChem, 2015, 2, 1687-1694.

124 X. Wang, E. Yasukawa and S. Mori, Electrochim. Acta, 2000, 45, 2677-2684.

125 R.-S. Kühnel, M. Lübke, M. Winter, S. Passerini and A. Balducci, J. Power Sources, 2012, 214, 178-184.

126 P. G. Bruce, S. A. Freunberger, L. J. Hardwick and J. M. Tarascon, Nat. Mater., 2011, 11, 19-29.

127 D. Aurbach, B. D. McCloskey, L. F. Nazar and P. G. Bruce, Nat. Energy, 2016, 1, 16128.

128 S. A. Freunberger, Y. Chen, Z. Peng, J. M. Griffin, L. J. Hardwick, F. Barde, P. Novak and P. G. Bruce, J. Am. Chem. Soc., 2011, 133, 8040-8047.

129 B. D. McCloskey, D. S. Bethune, R. M. Shelby, G. Girishkumar and A. C. Luntz, J. Phys. Chem. Lett., 2011, 2, 1161-1166.

130 M. M. Ottakam Thotiyl, S. A. Freunberger, Z. Peng and P. G. Bruce, J. Am. Chem. Soc., 2013, 135, 494-500.

131 D. M. Itkis, D. A. Semenenko, E. Y. Kataev, A. I. Belova, V. S. Neudachina, A. P. Sirotina, M. Havecker, D. Teschner, A. Knop-Gericke, P. Dudin, A. Barinov, E. A. Goodilin, Y. Shao-Horn and L. V. Yashina, Nano Lett., 2013, 13, 4697-4701.

132 B. L. Ellis, K. T. Lee and L. F. Nazar, Chem. Mater., 2010, 22, 691-714.

133 R. D. Rauh, K. M. Abraham, G. F. Pearson, J. K. Surprenant and S. B. Brummer, J. Electrochem. Soc., 1979, 126, 523-526.

134 H. Yamin and E. Peled, J. Power Sources, 1983, 9, 281-287.

135 Y. V. Mikhaylik and J. R. Akridge, J. Electrochem. Soc., 2004, 151, A1969-A1976.

136 R. Cao, K. Mishra, X. Li, J. Qian, M. H. Engelhard, M. E. Bowden, K. S. Han, K. T. Mueller, W. A. Henderson and J.-G. Zhang, Nano Energy, 2016, 30, 825-830.

137 K. Takada, Y. Yamada, E. Watanabe, J. Wang, K. Sodeyama, Y. Tateyama, K. Hirata, T. Kawase and A. Yamada, ACS Appl. Mater. Interfaces, 2017, 9, 33802-33809. 